\title{
AUNC
}

Zabytkoznawstwo i Konserwatorstwo XLIX

Toruń 2018

DOI: http://dx.doi.org/10.12775/AUNC_ZiK.2018.005

\section{Willa miejska Gustawa Plehwe przy ul. Mickiewicza 81 w Toruniu}

\section{JOANNA KUCHARZEWSKA}

Zakład Historii Sztuki Nowoczesnej Wydział Sztuk Pięknych, UMK w Toruniu

Joanna.Kucharzewska@umk.pl

ORCID: 0000-0002-4560-5658

Key words: Toruń, Przedmieście Bydgoskie, Gustaw Plehwe, urban villa, neo-renaissance

Słowa kluczowe: Toruń, Przedmieście Bydgoskie, Gustaw Plehwe, willa miejska, neorenesans

\section{Abstract}

\section{Gustav Plehwe's Urban Villa at 81 Mickiewicza Street in Toruń against the Background of Residential Buildings in the District of Przedmieście Bydgoskie}

The urban villa at 81 Mickiewicza Street is located in the district of Przedmieście Bydgoskie in Torun. It was built in the years $1890-91$ by Gustav Plehwe as his home and the headquarters of Ziegelei und Thonwaaren-Fabrik company. The construction changes taking place on the plot from the 70 s to the 90 s of the nineteenth century illustrated the typical process of spatial reorganization of the district, resulting from amendments to building regulations and liberalization of the regional construction restrictions.

The history of the plot development shows the gradual process of typological and architectural transformations. In the 70s of the nineteenth century, the plot had a modest tenement house on a rectangular plan with two avant-corps, covered with a gable roof, originally intended for three families. At the end of the 1880s, the first, unaccomplished, transformation attempts were made. In 1887, a neo-Renaissance tenement house was designed with two side annexes and a backyard outbuilding. 
Although the construction permit had been issued, the project was not completed. In 1889, another, more modest house design was created with one side annex and a one-story outbuilding. Yet again, that project was never completed.

In 1890, when the plot became the property of Gustav Plehwe, a construction entrepreneur, demolition works of the existing buildings were performed, followed by the construction of a representative urban villa in the Neo-Renaissance style. The planning of the two functions - a private home and a company's headquarters - determined the manner of its decoration and interior layout. The elaborate and sophisticated detail on the elevations (eastern and northern ones) reflected the company's building capabilities, promoted it and attracted potential investors. Additionally, spacious interiors, planned around the central hall, with enfilade rooms, ensured their comfortable use.

Gustav's Plehwe company dealt with the sale of construction products (clinker bricks, glazed bricks, radial bricks, ceramic moulding tiles, roof tiles), and it was also a licensed cement supplier of the Monier Gesellschaft company. Moreover, it performed building works, specializing in stucco and concrete constructions. The company displayed its products and presented its achievements at industrial exhibitions - e.g. in Königsberg in 1895, where it won the silver medal, and the following year at the West Prussian Industrial Exhibition in Grudziądz, where it was honoured with the gold medal. Gustav Plehwe's family had lived in the neo-Renaissance villa at 81 Mickiewicza Street until the beginning of the 20th century. Up to 1945 the house had served a residential function. After the war, the building was converted into a school - initially, it housed the Cooperative Secondary School, and later - the Secondary School of Economics no 2, before it was moved to Grunwaldzka Street (in the mid-1960s). In 1996, the building at 81 Mickiewicza Street was purchased by the regional newspaper office Nowości where it operated until 2004. Currently, residential functions have been restored in the building.

\section{Abstrakt}

Willa miejska przy ul. Mickiewicza 81 znajduje się na Przedmieściu Bydgoskim w Toruniu. Została wybudowana w latach 1890-1891 przez Gustawa Plehwe, jako siedziba jego rodziny oraz firmy Ziegelei und Thonwaaren-Fabrik. Zmiany budowlane zachodzące na działce od lat siedemdziesiątych do dziewięćdziesiątych XIX wieku obrazują typowy proces reorganizacji przestrzennej przedmieścia, wynikający ze zmian przepisów budowlanych oraz złagodzenia rejonowych ograniczeń budowlanych.

Historia zabudowy działki pokazuje stopniowy proces przekształceń typologiczno-architektonicznych. W latach siedemdziesiątych XIX wieku na działce znajdował się skromny dom czynszowy na planie prostokąta z dwoma ryzalitami, przekryty dwuspadowym dachem, przeznaczony pierwotnie dla trzech rodzin. Pod koniec lat osiemdziesiątych powzięto pierwsze - niezrealizowane - próby przekształceń. W 1887 roku powstał projekt neorenesansowej kamienicy czynszowej z dwiema oficynami bocznymi i oficyną tylną. Projekt mimo uzyskanego pozwolenia na budowę nie został wykonany. W 1889 roku powstał drugi, skromniejszy rysunek kamienicy z jedną 
oficyną boczną i parterowym budynkiem gospodarczym. Również i ta realizacja nie doszła do skutku.

W 1890 roku, kiedy działka stała się własnością przedsiębiorcy budowlanego Gustawa Plehwe, doszło do wyburzenia poprzedniej zabudowy i budowy reprezentacyjnej willi miejskiej w stylu neorenesansowym. Zaplanowanie dwóch funkcji - domu prywatnego i siedziby firmy - determinowało sposób dekoracji oraz układ wnętrza. Bogaty i finezyjny detal na elewacjach (wschodniej i północnej) pokazywał możliwości wykonawcze firmy, był jej reklamą i zachętą dla potencjalnych inwestorów. Z kolei przestronne wnętrza rozłożone wokół centralnego hallu i skomunikowane amfiladowo zapewniały komfortowe użytkowanie.

Firma Gustawa Plehwe zajmowała się sprzedażą asortymentu budowlanego (cegły klinkierowe, glazurowane, kominowe, ceramiczne kształtki, dachówki), była licencjonowanym dostawcą cementu firmy Monier Gesellschaft. Zajmowała się także wykonawstwem, specjalizując się w sztukateriach oraz konstrukcjach betonowych. Firma pokazywała swoje produkty i prezentowała osiągnięcia na wystawach przemysłowych - np. w 1895 roku w Królewcu, gdzie zdobyła srebrny medal, a w następnym roku na Zachodniopruskiej Wystawie Przemysłowej w Grudziądzu, podczas której została uhonorowana złotym medalem. Rodzina Gustawa Plehwe zamieszkiwała neorenesansową willę przy ul. Mickiewicza 81 do początku XX wieku. Budynek do 1945 roku pełnił funkcje mieszkalne. Po wojnie budynek zaadaptowano na szkołę - najpierw mieściło się tu Gimnazjum i Liceum Spółdzielcze, później Technikum Ekonomiczne nr 2 do czasu jego przeniesienia na ul. Grunwaldzką (w połowie lat sześćdziesiątych XX w.). W 1996 roku obiekt przy ul. Mickiewicza 81 zakupiła redakcja Dziennika Toruńskiego „Nowości”, gdzie funkcjonowała do 2004 roku. Obecnie w budynku przywrócono funkcje mieszkalne.

\section{Wstęp}

W południowej pierzei ul. Mickiewicza - pomiędzy poprzecznymi ulicami Kochanowskiego i Sienkiewicza - stoi neorenesansowa willa, do niedawna kojarzona z siedzibą lokalnego dziennika „Nowości” (fot. 1, 2). Na tym odcinku ulicy jest jedyną willą miejską, otaczają ją czynszowe kamienice i współczesne wielorodzinne bloki mieszkaniowe. Wolno stojący dom z bogatym detalem architektonicznym i sgraffitową dekoracją wyróżnia się na tle sąsiedniej pierzejowej zabudowy. Powstał w 1891 roku. Wcześniej w tym miejscu znajdowały się obiekty pochodzące z lat siedemdziesiątych XIX wieku.

\section{Ogólna sytuacja mieszkaniowa w Toruniu około 1871 roku}

W chwili proklamowania Cesarstwa Niemieckiego - tj. w styczniu 1871 roku w niewielkim przygranicznym i fortecznym mieście, jakim był wówczas Toruń, 
stało zaledwie 785 budynków mieszkalnych ${ }^{1}$. Historyczne centrum miasta było zatłoczone, a codzienne życie mieszkańców koncentrowało się głównie wokół Rynku Staromiejskiego i handlowej ulicy Szerokiej. W lokalnej prasie zwracano uwagę na potrzebę większego wykorzystania innych ulic starówki, a zwłaszcza Nowego Miasta. Potencjalnym miejscem rozwoju budownictwa mieszkaniowego były także tereny za miejskimi murami, jednak zabudowa przedmieść była w pierwszych latach pruskiego panowania wyraźnie ograniczana i blokowana przez Urząd Królewskiej Fortyfikacji. Według statystyk podanych przez Kazimierza Wajdę, w latach 1818-1831 z terenu oddalonego o około 600 metrów od centrum miasta ubyło 70 budynków - tj. z początkowego stanu obejmującego 177 obiektów zostało ich 107². Bezpośrednim powodem tych strat były regulacje prawne dotyczące Torunia. Według pruskich wojskowych względy obronno-strategiczne i ćwiczeniowe wymagały, by na terenach położonych najbliżej wałów obronnych nie było zabudowy utrudniającej prowadzenie działań zbrojnych ${ }^{3}$. Zgodnie z przepisami, pierwszy rejon forteczny stanowił otaczający fortyfikacje miasta pas szerokości około 560-600 metrów, na którym obowiązywały ścisłe rygory garnizonu, praktycznie wykluczające jakąkolwiek zabudowę. Dopuszczana była w tym rejonie lokalizacja cmentarzy (np. cmentarz św. Jerzego), chociaż pod warunkiem przestrzegania ustalonych norm, dotyczących nawet wysokości krzyży i nagrobków. Jakiekolwiek działania w pierwszym rejonie (np. urządzenie składowiska materiałów budowlanych, związana z poprawą infrastruktury podmiejskiej budowa dróg) wymagały oddzielnych pozwoleń. Drugi rejon forteczny obejmował pas oddalony od fortyfikacji na 800 kroków i szeroki na 500 kroków (odpowiednio: 560 i 350 metrów). Dopuszczano w nim budowę niewielkich kubaturowo obiektów, głównie w technice szkieletowej, $\mathrm{z}$ wypełnieniem ceglanym lub szachulcowym, zezwalano także na organizowanie składowisk materiałów budowlanych. W 1848 roku ustanowiono dla miast twierdz trzeci rejon forteczny - wyznaczony w odległości 1330 kroków

Kazimierz Wajda, „Pod ponownym pruskim panowaniem (1815-1920)”, w Toruń dawny i dzisiejszy. Zarys dziejów, red. Marian Biskup (Warszawa-Poznań-Toruń: PWN, 1983), 355.

2 Wajda, „Pod ponownym pruskim panowaniem”, 331.

3 Mirosław Giętkowski, Zbigniew Karpus i Waldemar Rezmer, Twierdza Toruń (Toruń: Duet, 2004), 49; Krzysztof Biskup, „Rejony ograniczeń budowlanych twierdzy gdańskiej w wiekach XIX i XX”, w Gdańsk. Pomnik historii, cz. 1, red. Artur Kostarczyk (Gdańsk: Regionalny Ośrodek Studiów i Ochrony Środowiska Kulturowego, 1998), 115-121 - w artykule porównano sytuację twierdzy Gdańsk i twierdzy Toruń w zakresie wprowadzanych ograniczeń rejonowych. 
(910 m) od fortyfikacji i szeroki na 470 kroków (ok. 350 m)4. Wraz z nastaniem Cesarstwa Hohenzollernów w grudniu 1871 roku weszła w życie ustawa wprowadzająca nowe przepisy dotyczące położenia rejonów fortecznych, ich odległość od murów miała wynosić odpowiednio: I rejonu - 600; II - 975; III - 2250 metrów 5 .

Otaczające Toruń tereny podmiejskie w okresie pruskim podzielono na tzw. stare i nowe przedmieścia. Jako „stare” określono historyczne przedmieścia, które znalazły się w pierwszym rejonie fortecznym; ich zabudowa - zgodnie z omówionymi przepisami - była w pierwszej połowie XIX wieku redukowana. „Nowe przedmieścia” stanowiły tereny w obrębie drugiego pasa fortecznego, które mogły być zagospodarowywane. W 1831 roku stało tam łącznie już 99 budynków mieszkalnych, czyli ich liczba była zbliżona do stanu na „starych przedmieściach” w tym samym czasie. Brakowało jednak odpowiednich powiązań urbanistycznych łączących „stare” i „nowe” przedmieścia zarówno między sobą, jak i z centrum miasta ${ }^{6}$.

\section{Kształtowanie się Przedmieścia Bydgoskiego}

W roku 1871 toruński publicysta dr Franciszek Rakowicz dzieląc się z czytelnikami „Gazety Toruńskiej” swoimi przemyśleniami na temat sytuacji w mieście stwierdził: „Znaną jest rzeczą, że w naszych okolicach najczęstsze wiatry są zachodnie. Dla tego [pisownia oryginalna] najzdrowsze dzielnice miasta, przez bogatszą ludność zamieszkałe, położone są ku zachodowi. U nas taką dzielnicą jest Przedmieście Bydgoskie [...] dla tego dbać trzeba, aby fabryki ze szkodliwymi wyziewami były zakładane na wschodniej stronie miast" ${ }^{8}$. Przedmieście Bydgoskie, położone wówczas w drugim rejonie fortecznym, między dzisiejszymi ulicami Konopnickiej (Parkstrasse) a Reja (Ulanenstrasse) $^{9}$, powszechnie uznawano za najbardziej dogodną lokalizację nowoczesnego osiedla mieszkaniowego. Cała okolica zachwycała walorami

\footnotetext{
Biskup, „Rejony”, 118.

Biskup, „Rejony”, 118; por. też http://twierdza.poznan.pl/kamienie/ (dostęp 30.05.2018).

Wajda, „Pod ponownym pruskim panowaniem”, 331.

Artykuł nie został podpisany; tezę o autorstwie dr. Franciszka Rakowicza postawił Szczepan Wierzchosławski, „Toruń w początkach 1871 roku. Obraz miasta w świetle ówczesnej Gazety Toruńskiej”, Rocznik Toruński 25 (1998): 39.

8 [Franciszek Rakowicz], „Nieco o sprawach miejskich w Toruniu”, Gazeta Toruńska 28 I 1871.

9 Tak określa obszar przedmieścia autor ówczesnego przewodnika po Toruniu, zob. Adolph Hermann, Neuer führer durch Thorn (Thorn: Dombrowski, 1877), 56.
} 
przyrodniczo-krajobrazowymi zarówno nowych mieszkańców, jak i okazjonalnych letników. W latach siedemdziesiątych XIX wieku, gdy Franciszek Rakowicz notował swoje spostrzeżenia, wzdłuż terasy wiślanej rozciągał się już ogród Królewskiego Gimnazjum, założony w 1797 roku przez botanika i doktora medycyny Johanna Gottlieba Schultza ${ }^{10}$, kontynuowano urządzanie parku angielskiego, formowanego przez połączenie Lasku Cegielni (Ziegelei Wäldchen) z Parkiem przy Cegielni (Ziegeleipark), wydzielono promenadę do jazdy konnej, otwarte już były pierwsze kawiarnie i restauracje (np. „Ziegelei Gasthaus").

Autor cytowanego artykułu zwrócił uwagę na związek między walorami dzielnicy a strukturą społecznościową. W ciągu XIX wieku podlegała ona dynamicznym zmianom. W latach sześćdziesiątych, kiedy na Przedmieściu Bydgoskim funkcjonowały tartaki, różne przedsiębiorstwa i składy budowlane najliczniejszą grupę zawodową stanowili pracownicy fizyczni (blisko 70\%) ${ }^{11}$. Po kilku dekadach, na przełomie XIX i XX wieku na Przedmieściu Bydgoskim mieszkało już ponad 20\% pracowników umysłowych, znaczny procent stanowili także właściciele i dzierżawcy oraz przedsiębiorcy (m.in. Gustaw Weese $\left.{ }^{12}\right)$.

Zmianom w strukturze społecznościowej stopniowo odpowiadały przekształcenia w sferze architektoniczno-urbanistycznej. W drugiej połowie lat siedemdziesiątych XIX wieku obraz Przedmieścia Bydgoskiego kształtowały głównie warsztaty, tartaki i składy budowlane. Wśród nich pojawiały się także budynki mieszkalne stawiane w konstrukcji szkieletowej, z wypełnieniem ceglanym - początkowo dość skromne pod względem opracowania artystycznego (np. ul. Bydgoska 44/46 i ul. Bydgoska 48).

Pierwsza zabudowa Przedmieścia Bydgoskiego koncentrowała się wzdłuż dróg prowadzących w kierunku zachodnim, w stronę Przysieka i dalej Bydgoszczy. Jako główną postrzegano wówczas ulicę określaną jako „Erste Linie” („pierwsza linia”), dopiero pod koniec lat osiemdziesiątych XIX wieku do

10 Ogród botaniczny został przekazany gimnazjum w 1828 r. zapisem testamentowym. Za: Marian Arszyński, Tadeusz Zakrzewski, Toruń. Miasto i ludzie na dawnej fotografii (do 1939 roku), red. Marian Biskup (Toruń: TNT, 1998), 182.

11 Marta Brodowska-Kowalska, „Struktura zawodowa przedmieść Bydgoskiego i Rybaki w Toruniu w latach 1866-1900”, Rocznik Toruński 42 (2015): 43; por. Katarzyna Dyl, „Socjotopografia Torunia przed I wojną światową na tle rozwoju gospodarczego i ludnościowego miasta w XIX i na początku XX wieku”, Rocznik Toruński 28 (2001): 102.

12 Joanna Kucharzewska, Historia rodziny Weese - fabrykantów toruńskich pierników i jej inwestycje budowlane w Toruniu (Toruń: UMK, 2017). 
oficjalnego obiegu weszła nazwa Brombergerstrasse (obecnie ul. Bydgoska). Równoległą do niej ulicę najpierw określano jako „Zweite Linie” („druga linia”), a następnie - od nazwiska burmistrza Gottlieba Melliena - Mellienstrasse (dziś ul. Mickiewicza) ${ }^{13}$. „Gazeta Toruńska” w 1893 roku instruowała: „Ulica Melliena na Przedmieściu Bydgoskim ma być odtąd pisana przez samo 'i’ a nie 'ie', czyli Mellin, a nie Mellien" ${ }^{14}$; ta zmiana w pisowni znajduje potwierdzenie w niepublikowanych materiałach źródłowych, np. pozwoleniach na budowę.

Jednym z wczesnych typów architektonicznych, jakie pojawiły się wzdłuż tych dwóch ulic („Erste” i „Zweite Linie”), był jednokondygnacyjny dom na planie prostokąta, nakryty wysokim, dwuspadowym dachem w układzie kalenicowym (czasami z facjatą), z zazwyczaj pośrodku usytuowanym wejściem i symetrycznie względem niego rozłożonymi otworami okiennymi. Jeszcze do niedawna można było spotkać kilka takich budynków ${ }^{15}$, obecnie został jeden, przy ul. Mickiewicza 65. W latach osiemdziesiątych XIX wieku budowano już domy o charakterze kamienic czynszowych. Były one dość niskie, nie przekraczały dwóch kondygnacji z poddaszem. W wystroju elewacji dominował styl klasycyzujący ${ }^{16}$, zdarzały się rozwiązania neorenesansowe, a także nieliczne przykłady niemieckiego Rohbau - budynku z wyeksponowaną ceglaną strukturą ${ }^{17}$.

W latach osiemdziesiątych XIX wieku na Przedmieściu Bydgoskim wytyczono pierwszą ulicę na linii północ-południe. Nastąpiło to w związku $\mathrm{z}$ budową powszechnej szkoły koedukacyjnej ${ }^{18} \mathrm{i}$ od tej - znaczącej dla dzielnicy - inwestycji, świadczącej o dynamice przyrostu mieszkańców przedmieścia, ulica wzięła nazwę: Schulstrasse (ob. ul. Sienkiewicza). Pierwsze oficjalne plany regularnego zagospodarowania terenu dzielnicy powstały w 1889

13 Biogram burmistrza zob. Karola Ciesielska, „Mellien Gottlieb”, w Toruński słownik biograficzny, t. 1, red. Krzysztof Mikulski (Toruń: UMK, 1998), 172-174.

14 Gazeta Toruńska 24 X 1893.

15 Budynki przy ul. Mickiewicza 85 (1878), ul. Mickiewicza 97 (1880), ul. Bydgoskiej 86 (1881) i 88 (1871).

16 Budynki przy ul. Bydgoskiej 94 (1884); ul. Klonowica 27 (1876); ul. Krasińskiego 100 (1890); ul. Mickiewicza 73 (1886); ul. Mickiewicza 101 (1885); ul. Mickiewicza 110 (1880); ul. Mickiewicza 113 (1889) itp.

17 Budynek przy ul. Bydgoskiej 68-70.

18 Szkoła została nadbudowana w 1898 r. przez Otto Schulza, zob. Joanna Kucharzewska, Architektura i urbanistyka Torunia w latach 1871-1920 (Warszawa: Neriton, 2004), 289-291. 
roku ${ }^{19}$. Ulicę graniczną II rejonu - a zarazem Przedmieścia Bydgoskiego - nazwano Ulanenstrasse (ob. ul. Reja), gdyż usytuowano przy niej (także w latach osiemdziesiątych) zespół koszar dla ułanów, mający częściowo zaspokoić niedobór miejsc kwaterunkowych dla dwóch tysięcy stacjonujących w Toruniu wojskowych ${ }^{20}$. W 1887 roku rozpoczęto prace przy drugim kompleksie koszarowym, przeznaczonym dla batalionu pionierów (saperów), na terenie od strony południowej ograniczonym Kasernenstrasse (ob. ul. Broniewskiego) ${ }^{21}$.

W latach dziewięćdziesiątych przystąpiono do budowy dodatkowych ulic na linii wschód-zachód. Wytyczono je w równej odległości od głównych ulic: pośrodku terenu między dzisiejszymi Bydgoską a Mickiewicza poprowadzono Kloßmannstrasse („Linie Ia”; ob. ul. Krasińskiego), a pomiędzy Mickiewicza a Broniewskiego - Waldstrasse („Linie IIa”; ob. ul. Słowackiego ${ }^{22}$. W tym czasie zabudowa Przedmieścia Bydgoskiego zaczynała się różnicować: obok domów szkieletowych, z coraz bogatszym detalem, powstawały czterokondygnacyjne kamienice czynszowe o cechach historyzujących oraz murowane wille jednorodzinne - ten ostatni typ reprezentuje budynek mieszkalny przy ul. Mickiewicza 81, pierwotnie należący do Gustawa Plehwe.

Kolejny etap zabudowy, który odzwierciedlił się stylistycznie w wyglądzie Przedmieścia Bydgoskiego, przypadł na czas od roku 1900 do końca pruskiej państwowości. W 1903 roku przesunięto granice I rejonu fortecznego w kierunku wschodnim, na linię dzisiejszej ul. Moniuszki, co umożliwiło zabudowanie pasa między tą ulicą a obecną ul. Konopnickiej. W 1909 roku zniesiono dotychczasowe rejonowe ograniczenia budowlane. Otworzyły się nowe per-

19 Więcej o kształtowaniu się dzielnicy w XIX w. zob. Joanna Kucharzewska, „Analiza historycznej kompozycji przestrzennej Przedmieścia Bydgoskiego i Rybaków od średniowiecza do 1914 roku" (dokumentacja konserwatorska, Toruń 2009, Archiwum WUKZ w Toruniu) - dokumentacja wykonana jako część opracowania dotyczącego obszarowego wpisu do rejestru zabytków. Por. też późniejszy przewodnik cyfrowy oparty na tej dokumentacji - Ilustrowana historia Bydgoskiego Przedmieścia w Toruniu, ostatnia modyfikacja 30.05.2018, http://bydgoskie.blox.pl/html/1310721,262146,21.html.

20 W 1880 r. Toruń miał 19,5 tys. mieszkańców, w tym ponad 2 tys. wojskowych - por. Gazeta Toruńska 5 II 1880.

21 O jednym z budynków zespołu koszar saperów - dawnym kasynie wojskowym - zob. Joanna Kucharzewska, Piotr Dąbrowski, „Program prac konserwatorskich dla budynku przy ul. Sienkiewicza 33 w Toruniu (dawne kasyno wojskowe)" (dokumentacja konserwatorska, Toruń 2017, Archiwum MKZ w Toruniu).

22 Drogi te pokrywają się z traktami pokazanymi na mapie z 1793 r. - zatem można założyć, że przetrwały okres napoleoński i stały się podstawą XIX-wiecznych prac urbanistycznych. Por. źródłowy materiał kartograficzny - Archiwum Państwowe w Toruniu (dalej: APT), Kart. 283, T. 471. Określenia „Linia Ia” i „Linia IIa” funkcjonowały jeszcze w 1892 r. 
spektywy rozwoju urbanistycznego i architektonicznego. Obiekty drugorzędne, o niskiej wartości estetyczno-artystycznej - zwłaszcza o przeznaczeniu gospodarczym (magazyny, drewutnie, stajnie) - burzono, by na ich miejscu zrealizować przemyślany plan rozwoju przestrzennego, zmieniając tym samym charakter nie tylko zabudowy, ale i całego przedmieścia ${ }^{23}$. Powstające w tym czasie kamienice wykazują cechy architektury wielkomiejskiej. Budynki osiągają wysokość czterech kondygnacji i użytkowego poddasza, są kilkuosiowe, wyposażone w ryzality, wykusze lub balkony, tworzą zwarte pierzeje o podobnych stylistycznie cechach (np. ul. Mickiewicza nr 52-62). U progu drugiego dziesięciolecia XX wieku dają się zauważyć awangardowe tendencje. Przejawiają się z jednej strony w pojedynczych obiektach nawiązujących do secesji, z asymetrycznie rozwiązanymi elewacjami i finezyjnym detalem architektonicznym (np. ul. Mickiewicza 20, rok 1911), z drugiej zaś w dążeniu do większych uproszczeń bryły oraz eliminacji rozdrobnionego i nadmiernego detalu (np. ul. Moniuszki 29). Ten brawurowo rozpoczęty proces zagospodarowywania terenów uwolnionych z ograniczeń fortecznych został przerwany przez wybuch pierwszej wojny światowej. Na zdjęciach lotniczych z 1925 roku dokładnie widać, że budynki powstałe w latach 1909-1914 stanowią pojedyncze enklawy mieszkaniowe, otoczone pustkami niezagospodarowanych kwartałów, czekającymi na odpowiedni czas inwestycyjny w kolejnych dziesięcioleciach.

Koncepcja zagospodarowania Przedmieścia Bydgoskiego zrodziła się mimo dziewiętnastowiecznych ograniczeń. Powstała dzięki fantazji i ambicji poszczególnych właścicieli, budowniczych i architektów. Za każdym domem, willą, kamienicą tej dzielnicy kryje się osobna historia - jedną z ciekawszych jest historia budowy willi Gustawa Plehwe przy ul. Mickiewicza 81.

\section{Historia budowy willi Gustawa Plehwe przy ul. Mickiewicza 81}

W pierwszej połowie XIX wieku działka przy ul. Mickiewicza, którą dziś zajmuje budynek mieszkalny pod numerem $81^{24}$, widniała w księgach hipotecz-

23 Dobrym przykładem zmian przestrzennych jest sposób zagospodarowania działki przy ul. Mickiewicza 28 opisany przy okazji inwestycji prowadzonych przez Franza Zährera - zob. Joanna Kucharzewska, „Wybrane inwestycje budowlane Franza Zährera w Toruniu”, Acta Universitatis Nicolai Copernici. Zabytkoznawstwo i Konserwatorstwo 45 (2014): 169.

24 Joanna Kucharzewska, „Karta ewidencyjna zabytku nieruchomego - Budynek mieszkalny przy ul. Mickiewicza 81 w Toruniu" (dokumentacja konserwatorska, Toruń 2018, Archiwum WUKZ w Toruniu). 
nych jako „Bromberger Vorstadt Nr 33a” („Przedmieście Bydgoskie nr 33a”) i rozciągała się między dzisiejszymi ulicami Mickiewicza (wówczas nazywaną po prostu „drogą z Torunia” - „Chaussee von Thorn”) oraz Krasińskiego (wtedy jeszcze niewytyczoną). W latach dwudziestych tego stulecia parcela należała do Jacoba Netzla ${ }^{25}$, który w 1851 roku sprzedał ją Marii Schick ${ }^{26}$.

W latach siedemdziesiątych w północnej części działki ówczesny właściciel August Ernst Thober wystawił - równolegle do drogi (ob. ul. Mickiewicza), od której oddzielał go przedogródek - murowany wielorodzinny budynek mieszkalny ${ }^{27}$ (fot. 3), założony na planie prostokąta, z dwoma skrajnymi ryzalitami. Nie jest znany widok elewacji, ale per analogiam można założyć, że część środkowa była zamknięta dwuspadowym dachem w układzie kalenicowym, a dwa boczne ryzality przechodziły w trójkątne facjaty z dwuspadowymi dachami w układzie poprzecznym. Zachowane rzuty z późniejszej przebudowy (por. fot. 4) pozwalają na zrekonstruowanie układu funkcjonalno-przestrzennego nieistniejącego już dziś budynku. Prawdopodobnie wydzielono w nim trzy niezależne mieszkania. Do mieszkania w ryzalicie wschodnim (po lewej stronie rzutu na fot. 4) wiodły drzwi umieszczone na trzeciej osi od wschodu. Za drzwiami wejściowymi znajdował się korytarz, którym można było się dostać do pokoju w przednim trakcie. Pokój ten połączony był w układzie amfiladowym z sypialnią w tylnym trakcie, a ta z kuchnią równej szerokości co korytarz. Pomieszczenie kuchenne miało osobne wyjście na podwórko w zachodniej ścianie ryzalitu. W części środkowej domu, czteroosiowej, wejście znajdowało się na drugiej osi od wschodu. Otwierało się na korytarz prowadzący do dwóch przeciwległych pokoi w przednim trakcie oraz do - umieszczonej na osi korytarza - kuchni w tylnym trakcie. Pokoje przedniego traktu skomunikowane były z pomieszczeniami o zbliżonym metrażu w tylnym trakcie. W kuchni było wyjście na podwórze. Do mieszkania w ryzalicie zachodnim wchodziło się przez drzwi umieszczone na drugiej osi od zachodu, wprost do korytarza, w którym znajdowały się schody wiodące na strych, a po prawej stronie wejście do pokoju w przednim trakcie. Pokój skomunikowany był z pomieszczeniem w tylnym trakcie o podobnej powierzch-

\footnotetext{
APT, Akta miasta Torunia (dalej: AmT), sygn. F 1031, k. 1-8.

APT, AmT, sygn. F 1031, k. 8.

27 August Ernst Thober kupił nieruchomość od Marii Franciszki Adolphiny Schick w 1871 r. APT, AmT, sygn. F 1031, k. 9; pozwolenie na budowę wydano w styczniu 1876 r. - APT, AmT, sygn. G 2617, k. 2.
} 
ni. W tylnym trakcie usytuowana była kuchnia oraz przedsionek, z wyjściem na podwórko (we wschodniej ścianie ryzalitu).

W roku 1879 właścicielami domu zostali David Marcus Lewin (kupiec) i jego żona Bertha (z domu Cohn $)^{28}$. Do rodziny Lewinów należały znaczne fragmenty Przedmieścia Bydgoskiego; z czasem były one sukcesywnie wysprzedawane pod prywatne inwestycje - np. wycinek na północ od ul. Mickiewicza, między dzisiejszymi ulicami Konopnickiej a Matejki. Tereny te - jak wspomniano wyżej - z powodu położenia w I rejonie fortecznym zostały zabudowane dopiero po przesunięciu granicy rejonu na linię ul. Moniuszki, czyli po 1903 roku. Wkrótce po nabyciu posesji Lewinowie przystąpili do przekształceń i niewielkich inwestycji. Wzdłuż zachodniej granicy działki stanął szkieletowy budynek stajni na planie prostokąta, a w czerwcu 1881 roku otrzymali zgodę na przebudowę domu ${ }^{29}$ (fot. 4). Zmiany w układzie przestrzenno-funkcjonalnym objęły część środkową oraz ryzalit zachodni. W części środkowej planowano przestawić wszystkie ściany wewnętrzne, co wiązało się z modyfikacją szerokości traktów - trakt przedni miał być szerszy, a tylny węższy. Schody przeniesiono do części środkowej domu, dzięki czemu powiększono pokój w ryzalicie zachodnim. Dotychczasowe otwory drzwiowe zamurowano, a nowe umieszczono na pierwszej osi od zachodu w części środkowej domu. Modernizacja domu świadczyła, że części środkową i zachodnią scalono dostosowując do potrzeb jednej rodziny. Część wschodnia, którą pozostawiono w dotychczasowym kształcie, nadal stanowiła oddzielne mieszkanie z osobnymi wejściami od ulicy i podwórka. W tym samym roku postawiono dodatkowe budynki gospodarcze przy wschodniej granicy działki.

Rozwój przestrzenny dzielnicy przy drugiej linii urbanistycznej (ob. ul. Mickiewicza), polegający na stopniowym wypełnianiu jej pierzei kamienicami czynszowymi, był wystarczającym impulsem do planowania podobnej inwestycji na działce o numerze 33a (ob. nr 81). W marcu 1887 roku na zlecenie nowego jej właściciela - Karla Bruschkowskiego mistrz murarski Franciszek Geittner przygotował projekt jedenastoosiowej kamienicy czynszowej $\mathrm{z}$ dwiema dwukondygnacyjnymi oficynami bocznymi oraz tylną piętrową zabudową gospodarczą (fot. 5). Trójkondygnacyjną kamienicę planowano wybudować w stylu neorenesansowym. Fasadę akcentowały trzy pseudoryzality - parter środkowego przecinał przejazd bramny prowadzący na po-

28 APT, AmT, sygn. F 1031, k. 16.

29 APT, AmT, sygn. G 2617, k. 20-21. 
dwórko. W dwóch bocznych ryzalitach znajdowały się wejścia na korytarze. Na końcu korytarzy, w tylnym trakcie, planowano umieścić klatki schodowe - niezależne dla każdej z dwóch części domu. Parter miał charakter użytkowy - zakładano, że będą tam sklepy. W oficynach bocznych i tylnej wprowadzono niezależną komunikację pionową. Na piętrach kamienicy rozplanowano przestronne mieszkania: w przednim, północnym trakcie pokoje i kuchnie, a w tylnym, południowym - mniejsze pomieszczenia (tzw. kamery). Projekt - mimo uzyskanego pozwolenia budowlanego (Bau-consens) ${ }^{30}$ - nie został zrealizowany. Gdyby dom według omówionego projektu powstał, stylistycznie nawiązywałby zapewne do takich obiektów, jak kamienica przy ul. Mickiewicza 67 i 74.

W tym czasie (1887 rok) od strony wschodniej działka graniczyła już z kamienicą czynszową Münthnera, która nosiła numer 33b (obecnie ul. Mickiewicza 79) ${ }^{31}$. Planowany budynek Karla Bruschkowskiego miał wypełniać całą szerokość działki i być dostawiony szczytem do sąsiedniej kamienicy, dając początek zwartej zabudowie pierzejowej. Rozwojowi budownictwa mieszkaniowego sprzyjały inwestycje municypalne. W 1889 roku działkę nr 33a przyłączono do kanalizacji miejskiej. Wydaje się, że na przeszkodzie planowanej budowy kamienicy czynszowej legły względy finansowe.

W lipcu 1889 roku powstał alternatywny projekt kamienicy - znacznie mniejszej - przygotowany przez innego budowniczego (nazwisko nie jest znane) (fot. 6). Planowano ją na rzucie kwadratu z oficyną boczną (piętrową z poddaszem) oraz parterowym budynkiem gospodarczym. Miała być podpiwniczona, dwupiętrowa z poddaszem. Na parterze zamierzano usytuować dwa sklepy z osobnymi wejściami od strony ulicy. Skromniejsze opracowanie artystyczne ograniczono do boniowania parteru, opasek okiennych i naczółków nadokiennych - trójkątnych na pierwszym i prostych na drugim piętrze. Prawdopodobnie zakładano etapowość inwestycji, gdyż w przyszłości można było wykonać lustrzane odbicie projektu i dopełnić zabudowę po wschodniej stronie działki. Również i to zamierzenie - mimo uzyskanego pozwolenia nie zostało zrealizowane ${ }^{32}$.

30 Pozwolenie na budowę wydano w marcu 1887 r. - APT, AmT, sygn. G 2617, k. 38.

31 Bruschkowski zgłaszał do urzędu Policji Budowlanej, że sąsiad wystawił mur ogniowy poza swoją granicą, tj. na jego działce - APT, AmT, sygn. G. 2617, k. 40, rys. „Situation der Grundstück den Eigenthümern Münther und Bruschkowski gehörig. Mellinstrasse Nr 33a-33b, Thorn".

32 Pozwolenie na budowę wydano w sierpniu 1889 r. - APT, AmT, sygn. G 2617, k. 52. 
Do zmiany zabudowy na działce doszło dopiero w latach dziewięćdziesiątych XIX wieku, kiedy jej właścicielem został mistrz murarski Gustaw Plehwe. W październiku 1890 roku złożył on w urzędzie policji budowlanej własny projekt domu z wolno stojącą oficyną, z prośbą o uzyskanie pozwolenia na budowę (uzyskał je w styczniu 1891 roku) ${ }^{33}$. Według projektu Plehwego - odmiennego od wcześniejszych koncepcji zagospodarowania działki - nie miał to już być budynek włączony w zwartą pierzeję, ale dom odsunięty od sąsiedniej, wschodniej kamienicy czynszowej, a także znacznie cofnięty względem tworzącej się wzdłuż ulicy Mickiewicza linii zabudowy. Dom przybrał kształt neorenesansowej willi miejskiej (fot. 7), choć należy przypuszczać, ze względu na dosunięcie jej do zachodniej granicy i planowaną elewację zachodnią bez otworów okiennych, że nie miała być wolno stojąca, ale bliźniacza (Doppelhaus). Takiej koncepcji nigdy nie zrealizowano, a - co więcej - charakter ulicy Mickiewicza został zdominowany przez pierzejową zabudowę czynszową, na linii biegnącej około czterech metrów bliżej ulicy niż fasada domu Gustawa Plehwego.

Willa wyróżniała się nie tylko nietypowym usytuowaniem na działce, ale także rozplanowaniem wnętrza i sposobem dekoracji. Założono ją na rzucie zbliżonym do kwadratu (o boku około 16 metrów). Elewacja północna (od ul. Mickiewicza) podkreślona była środkowym ryzalitem. Przeciwległa elewacja południowa miała loggię zajmującą dwie trzecie jej szerokości. W ryzalicie elewacji wschodniej umieszczono główne wejście, otwierające się na korytarz z klatką schodową (fot. 8). Po lewej znajdował się bieg prowadzący do piwnicy. Wszystkie pomieszczenia piwniczne sklepione były odcinkowo na stalowych belkach. Prawy bieg schodów prowadził na parter. Część mieszkalną od klatki schodowej oddzielały wieloskrzydłowe drzwi tworzące przepierzenie - i taki układ powtarzał się na każdej kondygnacji. Na poszczególnych piętrach centralne miejsce zajmował hall (Entree), skąd przechodzono do otaczających go pomieszczeń. W północnym trakcie wydzielono trzy pokoje (Stube) połączone ze sobą amfiladowo (na parterze i na drugim piętrze pomieszczenie wschodnie miało bezpośrednie wyjście na klatkę schodową). W tylnym trakcie znajdowały się dwa pomieszczenia (zachodnie i środkowe), a w części wschodniej kuchnia ze spiżarnią, pokój dla służących oraz toaleta. Wnętrza zapewne miały bogate wyposażenie; do dziś dotrwała jedynie nie-

33 APT, AmT, sygn. F 1031, k. 20; APT, AmT, sygn. G 2617, k. 57-90 (pozwolenie na budowę, projekty i zmiany budowlane). 
liczna stolarka drzwiowa o konstrukcji ramowo-płycinowej z ościeżynami oraz najcenniejszy zachowany element - betonowa klatka schodowa. Na jej dekoracyjnie rozwiązanym podniebieniu zastosowano cztery różne, odlewane motywy floralne wpisane w trójkątne pola ${ }^{34}$ (fot. 9), a na zewnętrznym policzku schodów wyciśnięto w betonie pojedynczy, koncentryczny ornament floralny (fot. 10).

Stylistyka budynku utrzymana była w typie neorenesansowej willi miejskiej. W załączonym do wniosku projekcie szczegółowo została rozrysowana elewacja północna ${ }^{35}$ (tj. od strony ul. Mickiewicza - por. fot. 7). Boniowany parter rozdzielały otwory okienne zamknięte pełnymi łukami. Krawędzie otworów podkreślono fakturalnym opracowaniem klińców w formie groszkowania $^{36}$. Planowana dekoracja w postaci pilastra hermowego między dwoma skrajnymi osiami elewacji nie została zrealizowana. Okna pierwszego piętra ujmowały pilastry, których trzony w dolnej części miały być dekorowane girlandami, ale zamiast nich wykonano płaskorzeźbione festony. Na projekcie elewacji północnej nie oznaczono miejsc, gdzie miała znaleźć się dekoracja sgraffito $^{37}$. Ostatecznie wypełniła ona powierzchnie między oknami poddasza (groteska i festony), pionowe pasy między oknami drugiego piętra (ornament kandelabrowy) oraz poziome pasy nadproży pierwszego i drugiego piętra (wić roślinna) (fot. 11).

34 Motyw 1: umieszczony przy ścianie koncentryczny, pojedynczy ornament floralny, od którego biegnie wić układająca się w antytetyczne fale, zwężające się zgodnie z układem trójkątnej płaszczyzny. Motyw 2: wić roślinna oparta na osi symetrii, układająca się w formie palmetek wychodzących jedna z drugiej i stopniowo zmniejszających się ku środkowi, zgodnie z układem trójkątnej płaszczyzny. Motyw 3: wić roślinna o antytetycznym układzie gałązek z dzwoneczkami (campanulle) na końcu, składająca się z siedmiu segmentów i zakończona trzema punktami; dekoracja zwęża się ku środkowi, zgodnie z układem trójkątnej płaszczyzny. Motyw 4: wić roślinna składająca się z dwóch liści akantu w układzie antytetycznym i przechodząca w gałązkę z liśćmi dębu; dekoracja zwęża się ku środkowi, zgodnie z układem trójkątnej płaszczyzny. APT, AmT, sygn. G 2617, k. 88.

36 Por Jeden z przykładów (budynek mieszkalny przy Leipzigerstrasse w Berlinie, proj. Becker \& Schlüter) podaje atlas niemieckich budynków mieszkalnych wydany jako reprint projektów z czasopisma „Zeitschrift für Bauwesen” z lat 1851-1904, zob. Manfred Berger, Atlas Wohnund Bürgerhäuser 1846-1902 (Berlin: Phoenix, 1986), Blatt 114.

37 Obecny stan dekoracji sgraffitowej jest wynikiem prac konserwatorskich przeprowadzonych w 1996 r. oraz rekonserwacji w 2017 r. - zob. Irena Bulderberg, „Dokumentacja prac konserwatorskich prowadzonych na elewacji północnej i wschodniej kamienicy przy ul. Mickiewicza 81 w Toruniu” (dokumentacja konserwatorska, Toruń 1996, Archiwum MKZ w Toruniu); Anna Zaręba, „Program prac konserwatorskich kamienicy przy ul. Mickiewicza $81 \mathrm{w}$ Toruniu” (dokumentacja konserwatorska,Toruń 2017, Archiwum MKZ w Toruniu). 
Projekty pozostałych elewacji były potraktowane schematyczne. Na elewacji wschodniej dominował ryzalit klatki schodowej, a w elewacji południowej na trzech kondygnacjach umieszczono loggie obejmujące cztery osie; loggia na parterze miała osobne zejście do ogrodu. W trakcie realizacji elewacja wschodnia otrzymała neorenesansowy wystrój, taki jak elewacja północna. Na elewacji południowej (por. fot. 2) zrezygnowano z dekoracji sztukatorskich, pozostała gładko tynkowana, a jedyną ozdobą były profilowane końcówki krokwi widoczne w głębokim okapie oraz żeliwna kolumienka podtrzymująca balkony.

Plastyczne rozwiązanie dwóch elewacji willi Gustawa Plehwe - wschodniej i północnej - wynikało z wyboru określonego stylu. Było ono zbieżne z klasycznymi i nowożytnymi zasadami kompozycyjnymi. Podstawowymi kategoriami porządkującymi były symetria i równowaga. W willi przy ul. Mickiewicza 81 są one bez wątpienia zachowane w fasadzie, natomiast w elewacji bocznej (wschodniej) widoczne jest lekkie zaburzenie symetrii: jeśli przyjąć, że osią symetrii byłby ryzalit z klatką schodową, to osie okienne po obu jego stronach nie są jednakowe. Jak jednak słusznie zauważają autorzy opracowania o łódzkich kamienicach, „w naturze symetria osiowa niemal nie występuje, podobnie w dziełach ludzkich nie musi mieć ona charakteru pełnej zgodności prawej i lewej strony. Za symetryczny uznamy także budynek (fasadę), którego strony mogą się delikatnie różnić" ${ }^{38}$. Kompozycja elewacji, której część stanowiła klatka schodowa, wymagała szczególnej uwagi projektanta, gdyż jej doświetlenia (okna) wypadały w połowie kondygnacji, co mogło zaburzać rytm i równowagę. Prezentację typowych rozwiązań także w tym zakresie - można znaleźć w podręczniku Alberta Geula z 1868 $\mathrm{roku}^{39}$. Autor przedstawił charakterystyczne rozplanowanie elewacji z centralnie umieszczoną klatką schodową jako ogólny schemat nadający się do wykorzystania w projektowaniu konkretnych budowli, sugerując możliwość przedłużenia gzymsów lub boniowania aż na ryzalit klatki schodowej, z przerwą w miejscach otworów. Dokładnie takie rozwiązanie prezentuje elewacja wschodnia toruńskiej willi. Jej ryzalit stanowi integralną część całej elewacji dzięki identycznemu opracowaniu tła - tj. boniowania na parterze i ceglanej

38 Michał Domińczak, Artur Zaguła, Typologia łódzkiej kamienicy (Łódź: Urząd Miasta Łodzi, 2016), 19.

39 Albert Geul, Die Anlage der Wohngebäude (Stuttgart: Weise, 1868), Blatt 160; Wolfgang Brönner, Die bürgerliche Villa in Deutschland 1830-1890 (Worm: Wernersche Verlagsgesellschaft, 1994), 116-117. 
faktury na wyższych kondygnacjach - oraz przeciągnięciu gzymsów, które urywają się dopiero na krawędziach otworów ryzalitu. Wyróżniające się innym kształtem i szkleniem okna klatki schodowej stanowią dekoracyjny element, podobnie jak na rysunku Alberta Geula, który - w przeciwieństwie do pozostałych prostokątnych okien elewacji - w ryzalicie klatki schodowej użył okien zamkniętych łukiem pełnym, a wyżej okien zdwojonych dla zaakcentowania tego fragmentu elewacji.

Opracowanie elewacji było dla dziewiętnastowiecznych projektantów najważniejszym zadaniem, bardzo często traktowanym autonomicznie, w oderwaniu od konstrukcji, a nawet funkcji obiektu ${ }^{40}$. Kwestie proporcji, równowagi, wyboru elewacji głównej i tylnej często wynikały z antropomorficznego widzenia architektury, które wywieść można z witruwiańskiego sposobu opisywania porządków. W XIX wieku popularne były poglądy Henri-Jacques’a Espérandieu, który dostrzegał zależności między postacią ludzką lub fizjonomią twarzy a architekturą ${ }^{41}$. W wilii Gustawa Plehwe fasadą jest elewacja zwrócona w kierunku ul. Mickiewicza, lecz wejście usytuowano w elewacji wschodniejej ${ }^{42}$ dlatego zrozumiałe wydaje się przyłożenie jednakowej wagi do plastycznego opracowania obydwu stron budynku. Jak wspomniano, przeciwległa, zachodnia elewacja zaplanowana była jako ślepa (bez otworów okiennych), co sugerować mogło zamierzaną rozbudowę - być może w charakterze Doppelhaus, na zasadzie lustrzanego odbicia. Odmiennie została potraktowana elewacja południowa - jest ona całkowicie pozbawiona okładzin oraz detalu architektonicznego, natomiast wyeksponowano na niej dwie żeliwne podpory balkonów, co należy postrzegać jako odważną manifestację użycia nowych technologii ${ }^{43}$.

40 Piotr Krakowski, „Fasada dziewiętnastowieczna”, Zaszyty Naukowe UJ. Prace z Historii Sztuki 16 (1981): 55-95.

${ }^{41}$ Henri-Jacques Espérandieu, „Le Sentiment et l`architecture. De la forme et de la coloration des édifices”, Revue générale de l'architecture et des travaux publics 29 (1872): 52 - za: Krakowski, „Fasada”, 59. Obecne wejście w elewacji od strony ul. Mickiewicza wykonano wtórnie w $1996 \mathrm{r}$.

43 Gottfried Semper jeszcze w 1884 r. powątpiewał, czy nowoczesne technologie budowlane wykorzystujące żelazo i stal na tyle zyskają uznanie, by skłonić architektów do eksponowania tych materiałów na równi z kamieniem, cegłą i drewnem - chociaż akceptował użycie owych technologii do konstrukcji inżynieryjnych, np. hal dworcowych: „Es wird noch lange dauern, bis das Eisen, und überhaupt das Metall, welches erst wieder in seine Rechte als Baumaterial eingetreten ist, auf eine so vollkommene Weise technisch beherrscht sein wird, daß es als künstlerisches Element in der schönen Baukunst neben dem Steine, den Ziegeln und dem Holze Geltung und Würdigung zu finden beanspruchen darf“ - Gottfried Semper, Kleine Schriften (Berlin-Stuttgart: W. Spemann, 1884), 484. 
W XIX wieku uważano, że w sposobie opracowania elewacji, w ich rozwiązaniach plastyczno-estetycznych ujawnia się geniusz architekta. Bardzo często jednak w osiągnięciu prawdziwego mistrzostwa stały na przeszkodzie względy finansowe, które wymuszały użycie tańszych, gotowych detali katalogowych, oferowanych przez firmy budowlane. Willa Gustawa Plehwe - mimo zastosowania tynkarskiego boniowania (a nie kamiennego) ${ }^{44}$ oraz detalu architektonicznego w formie odlewów - prezentuje wysoką jakość estetyczną i stanowi cenny przykład wolno stojącej neorenesansowej willi miejskiej. Na szczególne podkreślenie zasługuje zwłaszcza dekoracja sgraffitowa z motywami groteski, która w toruńskiej willi wypełnia płyciny między oknami oraz pasy nadproży. W drugiej połowie XIX wieku technika sgraffitowa na terenie Niemiec i Austrii cieszyła się dużą popularnością. Znacząco przyczynił się do tego Gottfried Semper, który użył jej do dekoracji drezdeńskiej opery, politechniki w Zurychu oraz elewacji prywatnych domów. W Kolonii sgraffito wykorzystywali Gustav Eberlein, Walter Kyllmann i Adolf Heyden ${ }^{45}$. W środowisku berlińskim, które mogło mieć największy wpływ na upowszechnienie tego typu ornamentacji, stosowali ją m.in. Hugo Licht $^{46}$ oraz Hermann Ende i Wilhelm Böckmann ${ }^{47}$. Podobny do toruńskiego detal z motywem groteski - umieszczony w kwadratowych płycinach tuż poniżej gzymsu wieńczącego zdobił willę Wesendonck w Berlinie autorstwa architekta Christiana Heidecke. Jej projekt prezentowany był w branżowym czasopiśmie „Zeitschrift für Bauwesen” w 1890 roku $^{48}$, co mogło przyczynić się do popularyzacji motywu także poza Berlinem. Również zbieżność dat powstania berlińskiej i toruńskiej willi miejskiej pozwala stawiać ostrożną tezę o wpływie rozwiązań plastycznych stosowanych w stolicy Prus. Oczywiście jak pokazują inne przykłady w Toruniu - wzorce berlińskie przejmowane i realizowane na gruncie lokalnym zazwyczaj uzyskiwały skromniejszą postać. Niestety na tym etapie badań nie udało się ustalić, czy toruńskie sgraffito

44 Różne formy „udawane” (w tym boniowanie w tynku) były przedmiotem krytyki Jana Sas-Zubrzyckiego: „Na wapnie lub gipsie udajemy sklepienia ceglane lub mury z cegły. Na murze ceglanym udajemy gładkie kamienie, nasiekane ostro lub tzw. boniowanie, to znaczy obramowane i w pośrodku mocno wystające” - Jan Sas-Zubrzycki, „Założenia. Szereg spostrzeżeń i uwag z dziedziny architektury”, Przegląd Techniczny 45 (1908): 542.

45 W. Brönner, Die bürgerliche Villa, il. 49, 50.

46 Hugo Licht, Die Architektur Berlins. Sammlung hervorragender Bauten der letzten zehn Jahre (Berlin: Wasmuth, 1877).

47 Franziska Pagel, Ende \& Böckmann. Ein Berliner Architekturbüro im 19 Jahrhundert (Berlin: Mann, 2019).

48 Zeitschrift für Bauwesen 40 (1890), Blatt 24, 25, Seite 175-178; Berger, Atlas, Blatt 128. 
było dziełem właściciela obiektu, czy też zostało wykonane przez innego mistrza, specjalnie zatrudnionego do tego celu. Utrudnia to również spekulacje na temat ewentualnych inspiracji. Samo zastosowanie tej techniki wszakże świadczy, że dekoracja elewacji była wynikiem przemyślanej i wyrafinowanej wizji estetycznej, a nie konglomeratu tandetnych form katalogowych.

W XIX wieku zarówno teoretycy architektury, jak i projektanci szczególnie podkreślali potrzebę prezentowania na elewacjach określonego programu ideowego. Idea przewodnia bądź alegoryczny przekaz mogły się zawierać w konkretnej stylizacji. Toruński przedsiębiorca wybrał dla swego domu formy neorenesansu. Elegancka willa miejska, w której pobrzmiewały echa włoskiej tradycji przefiltrowanej przez pożądane na terenie Prus wątki niemieckiego renesansu, przypominała o ideałach mieszczaństwa, była wizytówką dobrze prosperującej firmy, synonimem luksusu ${ }^{49}$.

W październiku 1890 roku Gustaw Plehwe otrzymał pozwolenie na wybudowanie murowanej, piętrowej oficyny według własnego projektu (fot. 12). Postawił ją wzdłuż zachodniej granicy działki, zamykając pulpitowym dachem ze spadkiem w kierunku podwórka. Pełniła funkcję wozowni i stajni. Oficyna nadal stoi, ale została otynkowana i nie przypomina dawnego obiektu w charakterystycznej dla XIX wieku stylizacji Rohbau ${ }^{50}$.

W 1891 roku zapewne oba budynki były już gotowe. Willę poprzedzał tzw. przedogródek, a na jej tyłach rozciągał się ogród. Teren posesji otoczono ogrodzeniem złożonym z murowanych cokołów i słupków oraz metalowych przęseł (krat) ${ }^{51}$. Główna brama wjazdowa, usytuowana po stronie wschodniej, miała być - według projektu - ozdobiona metaloplastycznym szyldem z napisem: G.Plehwe Maurermeister No 33 (fot. 13).

Gustaw Plehwe dbał o reklamę i promocję własnego nazwiska, gdyż prowadził dobrze prosperującą firmę budowlaną - Ziegelei und Thonwaaren-Fabrik oferującą różnorodne materiały budowlane (fot. 14) (magazyn znajdował się w Antoniewie koło Lubicza). Po wybudowaniu willi na ul. Mic-

49 Na taką interpretację wskazywali ówcześni teoretycy i krytycy sztuki, np. Kazimierz Brodziński, który jako sekretarz Królewskiego Uniwersytetu Warszawskiego podróżował do Niemiec i poznał architekturę tego kraju. W Kursie estetyki sformułował ogólną uwagę na temat budownictwa świeckiego: „Inną wcale piękność i inny charakter mieć muszą pałace, które już nie wzniosłe uczucia religijne, ale zamożność, powagę i smak mieszkańców oznaczać mają” - Kazimierz Brodziński, „Kurs estetyki, cz. II”, w Pisma Kazimierza Brodzińskiego, t. 6 (Poznań: Gebethner i Wolff, 1873), 201-202.

50 APT, AmT, sygn. G 2617, k. 82.

51 Pozwolenie na budowę ogrodzenia uzyskano w lipcu 1891 r. - APT, AmT, G 2617, k. 99. 
kiewicza 81 przeniósł do niej swoje biuro, w którym podłączono telefon o numerze 74. Na asortyment dostępny w firmie Gustawa Plehwe składały się m.in. cegły klinkierowe, glazurowane, kominowe, specjalistyczne (np. do murowania studni), ceramiczne kształtki i tzw. cegła klasztorna; miał również ceramiczne dachówki. Firma wykonywała prace budowlane w całym Toruniu. Jedną ze znakomitszych realizacji Gustawa Plehwe była przebudowa w latach 1887-1888 kamienicy przy ul. Mostowej 30, należącej wówczas do kupca Ludwiga Berga, właściciela sklepu meblowego ${ }^{52}$. W 1902 roku tę reprezentacyjną kamienicę w stylu północnego neorenesansu przejęli bracia Franz i Richard Tews tworząc modny salon meblowy - oferujący również artykuły wyposażenia i wystroju wnętrz - pod słynnym w Toruniu szyldem Gebrüder Tews. Firma Gustawa Plehwe była równie znana w środowisku toruńskim, a dodatkowo dzięki kontaktom handlowym zyskała na znaczeniu i rozszerzyła swój zasięg poza rynek lokalny. Specjalizowała się w sztukateriach oraz konstrukcjach z cementu, czego potwierdzeniem jest klatka schodowa w domu-biurze przy ul. Mickiewicza 81. Gustaw Plehwe był licencjonowanym dostawcą cementu produkowanego przez Monier Gesellschaft. Firma toruńskiego przedsiębiorcy prezentowała swoje produkty i osiągnięcia budowlane na wystawach przemysłowych - np. w 1895 roku w Królewcu zdobyła srebrny medal, a w następnym roku na Zachodniopruskiej Wystawie Przemysłowej w Grudziądzu-została uhonorowana złotym medalem ${ }^{53}$.

Posesja Gustawa Plehwe, początkowo oznaczona jako „Bromberger Vorstadt Nr 33a”, w latach dziewięćdziesiątych XIX wieku zmieniła adres na Mellienstrasse (Mellinstrasse) $103^{54}$. Działka rozciągała się w kierunku południowym aż do dzisiejszej ulicy Krasińskiego i jej południowa część miała własny numer hipoteczny: „Bromberger Vorstadt Nr 229” - obecnie jest to również osobny adres (ul. Krasińskiego 84). Na tej części działki w 1899 roku Gustaw Plehwe postanowił wybudować niezależny dom ${ }^{55}$. Piękna neogotycka willa stanowi oddzielny temat, wykraczający poza ramy niniejszego artykułu.

Rodzina Gustawa Plehwe zamieszkiwała neorenesansową willę przy ul. Mickiewicza 81 do początku XX wieku. W 1901 roku właścicielem dział-

\footnotetext{
52 Joanna Kucharzewska, „Kwerenda archiwalna dotycząca budynków przy ul. Mostowej 30 i Podmurnej 29 w Toruniu" (dokumentacja konserwatorska, Toruń 2018, Archiwum MKZ w Toruniu).

53 APT, AmT, sygn. G 2617, k. 151.

54 APT, AmT, sygn. F 1031, k. 19.

55 APT, AmT, sygn. G 2617, k. 144-159.
} 
ki został mistrz piekarski Peter Gehrz. W 1909 roku posesję kupił Hermann Schielke, który dokonał modernizacji poddasza willi, polegającej m.in. na wstawieniu nowych ścianek działowych i dodaniu świetlika w dachu ${ }^{56}$. W roku 1903 w ogrodzie wybudowano drewnianą altanę; w 1921 roku była już bardzo zniszczona i magistrat domagał się od właścicielki Józefy Majewskiej rozebrania konstrukcji zagrażającej bezpieczeństwu ${ }^{57}$. Uwagę urzędu zwróciła także adaptacja pomieszczeń strychowych na mieszkanie oraz pralnię i suszarnię, wykonana w 1928 roku bez stosownego zezwolenia administracyjnego ${ }^{58}$. W latach trzydziestych właścicielem willi był Roman Pincel ${ }^{59}$, który w roku 1938 zgłaszał chęć postawienia ścianek działowych na drugim piętrze, a w następnym - na parterze. W ostatniej dekadzie lat przed drugą wojną w budynku miał również siedzibę III Posterunek Policji Państwowej w Toruniu.

Po odzyskaniu polskiej państwowości w 1920 roku zmieniono nazwę ulicy - Mellienstrasse przemianowano na ul. Mickiewicza. Na początku lat trzydziestych zweryfikowano numerację domów i willa otrzymała nowy adres: ul. Mickiewicza 81. W latach hitlerowskiej okupacji powrócono do niemieckiego nazewnictwa i adres willi ponownie brzmiał: Mellienstrasse 81 . Po drugiej wojnie światowej, w roku 1946 budynek przy ul. Mickiewicza 81 zaadaptowano na szkołę - działało tu Państwowe Spółdzielcze Liceum Handlowe i Państwowa Roczna Szkoła Przysposobienia Spółdzielczego. W 1947 roku powstał projekt świetlicy dla zespołu szkół spółdzielczych - drewniany obiekt na planie prostokąta, przekryty dwuspadowym dachem opartym na kratownicowych wiązarach, planowano postawić na wolnym terenie po stronie zachodniej w głębi działki ${ }^{60}$. W 1951 roku przeprowadzono remont budynku, a Liceum Handlowe przekształcono na Technikum Ekonomiczne nr 2, które mieściło się tu do 1965 roku, do czasu przeniesienia do nowo wybudowanego obiektu przy ul. Grunwaldzkiej. Następnie przez kilkanaście lat budynek zajmowała Zasadnicza Szkoła Zawodowa Dokształcająca. W roku 1981 umieszczono w nim siedzibę Zarządu Regionu Toruńskiego Niezależnego Samorządnego Związku Zawodowego „Solidarność”. W 1996 roku obiekt przy ul. Mickiewicza 81 zakupiła redakcja Dziennika Toruńskiego „Nowości”, która zleciła wykonanie generalnego remontu, za który wykonawca otrzymał

\footnotetext{
APT, AmT, sygn. G 2617, k. 208.

APT, AmT, sygn. G 2617, k. 221.

APT, AmT, sygn. G 2617, k. 226.

APT, AmT, sygn. G 2618, k. 1.

60 APT, AmT, sygn. G 2618, k. 3.
} 
nagrodę ${ }^{61}$. Jedną z poważniejszych dokonanych wówczas zmian było usytuowanie głównego wejścia od strony ul. Mickiewicza - czyli w miejscu, gdzie wcześniej nie występowało. Przekształcenie dwóch środkowych otworów $\mathrm{z}$ okien na drzwi (pod względem budowlanym wykonane poprawnie) pociągnęło za sobą pewne konsekwencje w układzie funkcjonalno-przestrzennym. Środkowe pomieszczenie na parterze przyjęło funkcję nowego hallu, w którym umieszczono także wtórne ścianki o konstrukcji ramowo-płycinowej wydzielające wiatrołap. Nowe wejście poprzedzono zewnętrznymi schodami, pod którymi zainstalowano system grzewczy, co w latach dziewięćdziesiątych XX wieku było swoistą innowacją ${ }^{62}$. Od sierpnia 1997 roku, obok Zarządu Regionu NSZZ „Solidarność”, w willi działała również redakcja „Nowości”. Po roku 2004, tj. po opuszczeniu budynku przez redakcję, pomieszczenia w nim wynajmowały równocześnie różne firmy. W lutym 2017 roku obiekt zakupiła prywatna firma, która przeprowadziła remont i adaptację wnętrz na mieszkania. Tym samym po siedemdziesięciu latach przerwy (od 1947 roku) willi przywrócona została funkcja mieszkalna.

\section{Podsumowanie}

Willa miejska przy ul. Mickiewicza 81, wybudowana w latach 1890-1891 przez Gustawa Plehwe jako siedziba jego rodziny oraz firmy Ziegelei und Thonwaaren-Fabrik, stanowi reprezentatywny przykład architektury Przedmieścia Bydgoskiego - zachodniej dzielnicy mieszkaniowej Torunia. Gustaw Plehwe, występujący tu jednocześnie w roli inwestora, projektanta i wykonawcy, wybierając neorenesansowy kostium elewacji zaprezentował własny pogląd na kształt prywatnej willi miejskiej. Trzeba przyznać - pogląd zbieżny z postawą umacniającej się wówczas burżuazji, poszukującej nobilitacji w wystawnej i bogatej oprawie własnego życia, a architektura doskonale nadawała się do takiej manifestacji ${ }^{63}$. Styl zapewne nie został przez Gustawa Plehwe

${ }^{61}$ Generalnym wykonawcą prac konserwatorskich była firma Relief s.c. z Torunia, zob. Bulderberg, „Dokumentacja”.

62 Szymon Spandowski, „Nowości w tym roku kończą 50 lat”, Nowości 8 X 2017; Szymon Spandowski, „Na marginesie jubileuszu Nowości”, Nowości 16 X 2017.

63 Piotr Krakowski tłumaczył sięganie po kostium historyczny w następująco: „Kryterium przeszłości wydawało się tym ludziom najłatwiejsze do przyjęcia, a równocześnie najbardziej pewne i sprawdzone. Łączyła się owa postawa także z pewnym snobizmem klasy społecznej bez przeszłości - stąd chęć naśladowania warstw historycznych oraz nawiązywania do tradycji” - Piotr Krakowski, „Z zagadnień architektury XIX wieku. Historyzm i eklektyzm”, w Sztuka 2 poł. XIX wieku. Materiały sesji SHS, (Warszawa: PWN, 1973), s. 35-36. 
wybrany przypadkowo. W końcu XIX wieku neorenesans miał już ugruntowaną pozycję ${ }^{64}$ architekci wykorzystywali jego formy przy projektowaniu fasad - zarówno kamienic, jak i rezydencji, a bankierzy, przedsiębiorcy, przemysłowcy, nuworysze chętnie go wybierali, gdyż jak żaden inny styl budził skojarzenia z bogactwem i luksusem ${ }^{65}$. Neorenesans stał się nośnikiem wątków znaczeniowych i symboli ważnych dla bogacącego się mieszczaństwa i postępu. Dodatkowo istniała pewna łatwość w wyborze różnorodnych elementów, swoboda kompilacji motywów, dowolność zestawień, gdyż projektanci nie byli skrępowani klasycznymi regułami, choć używane detale miały proweniencję klasyczną. Gustaw Plehwe w swojej willi zastosował m.in. astragal, fryz ząbkowy, modyliony, a także dekorację sgraffitową z motywem groteski. Technika sgraffita zyskała popularność w środowisku berlińskim w drugiej połowie XIX wieku, kiedy projektanci zaczęli szczególnie interesować się rodzimą architekturą nowożytną, inspirować się nią i w końcu włączać pojedyncze motywy dekoracyjne do swoich projektów ${ }^{66}$. Zapewne rozpowszechnienie techniki sgraffitowej w stolicy Prus wpłynęło na decyzję o sposobie

64 Według Marka Zgórniaka neorenesans prawdziwą popularność na terenie Prus zdobył dopiero po wojnie prusko-francuskiej; zob. Marek Zgórniak, „Wokół neorenesansu w architekturze XIX wieku. Podstawy teoretyczne i realizacje”, Zeszyty Naukowe UJ. Prace z Historii Sztuki 18 (1987): 105, oraz w osobnej publikacji: Marek Zgórniak, Wokół neorenesansu w architekturze XIX wieku. Podstawy teoretyczne i realizacje (Kraków: Marek Zgórniak, 2013): 165. Zob. też Tadeusz Stefan Jaroszewski, „Kostium francuski architektury polskiej 2 poł. XIX w.”, w Od klasycyzmu do nowoczesności, red. Tadeusz Stefan Jaroszewski, (Warszawa: PWN, 1995); Jan Skuratowicz, ,'Wersale północy’, czyli o rezydencjach europejskich 2 poł. XIX w.”, w Tradycja i innowacja. Materiały z sesji SHS, (Warszawa: PWN, 1981), 241; Wojciech Bałus, „Zjawisko historyzmu w architekturze wieku XIX. Próba opisu”, Dzieła i Interpretacje 3 (1995): 69-80; Wojciech Bałus, „Renesans w wieku XIX i XX: fascynacja i sprzeciw”, w Recepcja renesansu w wieku XIX i XX. Materiały z sesji SHS, (Łódź: Stowarzyszenie Historyków Sztuki, Muzeum Kinematografii, 2003), 11-33; Zdzisława Tołłoczko, „Kostium francuski w architekturze XIX wieku i jego recepcja na ziemiach Polski na przykładzie pałaców w Świerklańcu i Kronenberga w Warszawie, Wiadomości Konserwatorskie 48 (2016): 106-118.

66 Dieter Dolgner wskazywał, że około połowy XIX w. nastąpił wyraźny zwrot ku formom rodzimego renesansu - zob. D. Dolgner, „Die nationale Variante der Neurenaissance in der deutschen Architektur des 19. Jahrhunderts", Wissenschaftliche Zeitschrift der Hochschule für Architektur und Bauwesen Weimar 20 (1973): 155. Jednym z pierwszych przejawów czerpania z niemieckich wzorów nowożytnych była przebudowa zamku w Schwerinie w $1844 \mathrm{r}$. oraz budowa kościoła św. Marka w Berlinie w 1846 r., zob. Friedrich Schlie, Die Kunst- und Geschichts-Denkmäler des Grossherzogthums Mecklenburg-Schwerin, t. 2 Die Amtsgerichtsbezirke Wismar, Grevesmühlen, Rehna, Gadebusch und Schwerin (Schwerin: Bärensprungschen Hofbuchdr, 1898; reprint: Schwerin: Forgotten Books, 1992); Eva Börsch-Supan, Berliner Baukunst nach Schinkel 1840-1870 (München: Prestel, 1977). 
wypełnienia płycin na elewacjach domu Plehwego, które jeszcze na rysunkach projektowych widniały bez dekoracji ${ }^{67}$.

Zmiany budowlane zachodzące na działce „Bromberger Vorstadt Nr 33a” (ob. Mickiewicza 81) w trzech ostatnich dekadach XIX wieku obrazują typowy proces reorganizacji przestrzennej przedmieścia, wynikający ze zmian przepisów budowlanych oraz złagodzenia rejonowych ograniczeń budowlanych. Historia zabudowy działki jest przykładem stopniowych przekształceń typologiczno-architektonicznych: od skromnego domu czynszowego, przez projekt (niezrealizowany) kamienicy czynszowej z oficynami, do willi miejskiej bogatego przedsiębiorcy. Połączenie dwóch funkcji - prywatnego domu i siedziby firmy - determinowało sposób dekoracji oraz układ wnętrza. Bogaty i finezyjny detal na elewacjach (wschodniej i północnej) pokazywał - oprócz wspomnianych wyżej treści ideologicznych - możliwości wykonawcze firmy, był jej reklamą i zachętą dla potencjalnych inwestorów. Z kolei przestronne wnętrza - rozłożone wokół centralnego hallu i skomunikowane amfiladowo - zapewniały komfortowe użytkowanie. Zastosowanie w willi cementu jako podstawowego materiału do konstrukcji klatki schodowej świadczyło o wiedzy właściciela na temat produktu, który był w stałej sprzedaży firmy, oraz umiejętności w jego stosowaniu. Potwierdzało również zainteresowanie lokalnego przedsiębiorcy możliwościami technicznymi tkwiącymi w betonie - materiale, który był elastyczny i wytrzymały, pozwalał na dość szybkie tworzenie gotowych prefabrykatów, a jednocześnie miał walory dekoracyjne. W zaprojektowanej przez siebie klatce schodowej Plehwe przetestował wszystkie te możliwości - wytrzymałość betonowej konstrukcji, użycie prefabrykowanych odlewów (tu z floralnym deseniem w czterech różnych kombinacjach) oraz efekt dekoracji (tu wyciskanych w formie stempli). Świadczy to o eksperymentalnym i kreatywnym podejściu do betonu, który przecież w tym czasie nie był wykorzystywany jeszcze na skalę masową.

Willa miejska przy ul. Mickiewicza $81 \mathrm{z}$ jednej strony jest typowym przykładem architektury doby historyzmu, z drugiej strony reprezentuje wartości jednostkowe, indywidualne, wynikające z nieprzeciętnej roli, jaką odegrał właściciel - przedsiębiorca budowlany, licencjonowany sprzedawca cementu i zdolny projektant.

${ }^{67}$ O technice sgraffitowej jako popularnym motywie dekoracji fasad zob. także Krakowski, „Fasada", 68-70. 


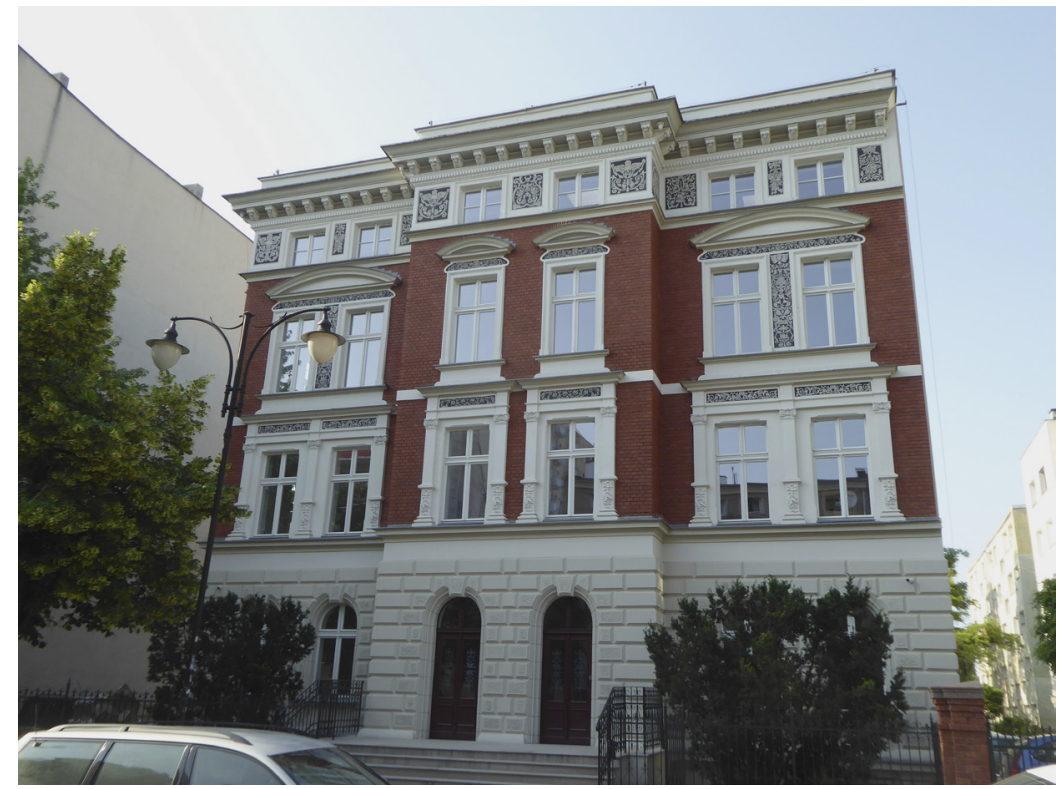

1. Willa miejska przy ul. Mickiewicza 81 w Toruniu, widok ogólny elewacji północnej. Fot. J. Kucharzewska, 2018

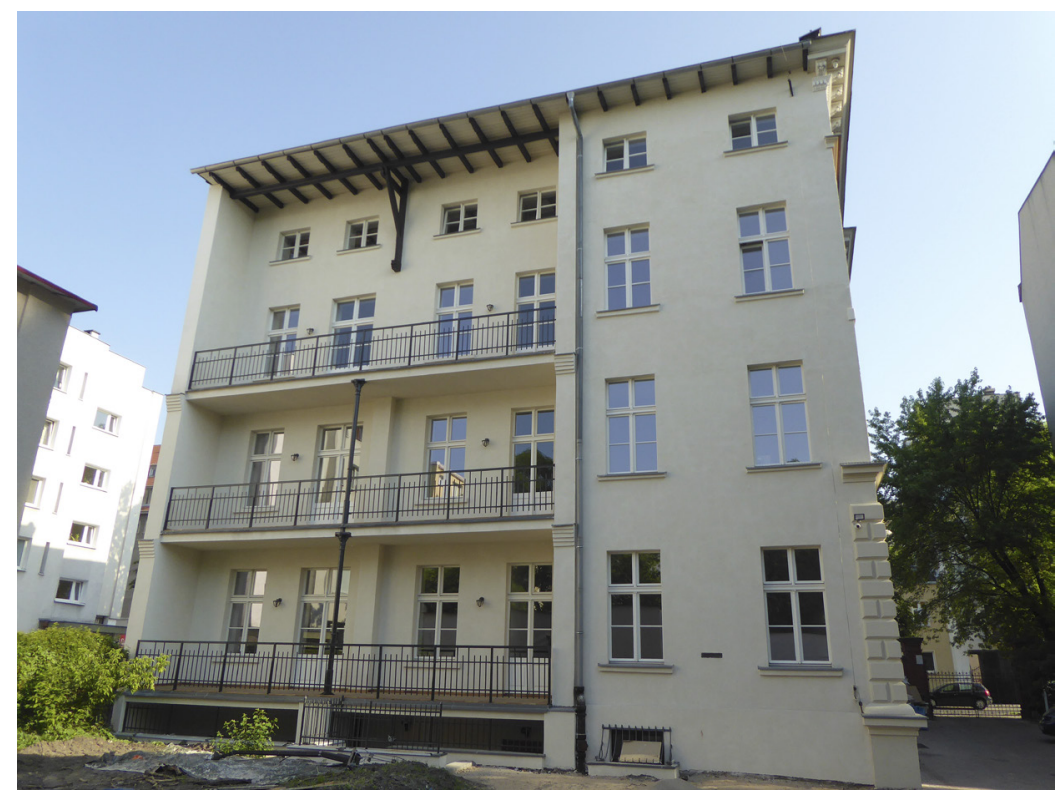

2. Willa miejska przy ul. Mickiewicza 81 w Toruniu, widok ogólny od strony południowo-wschodniej. Fot. J. Kucharzewska, 2018 


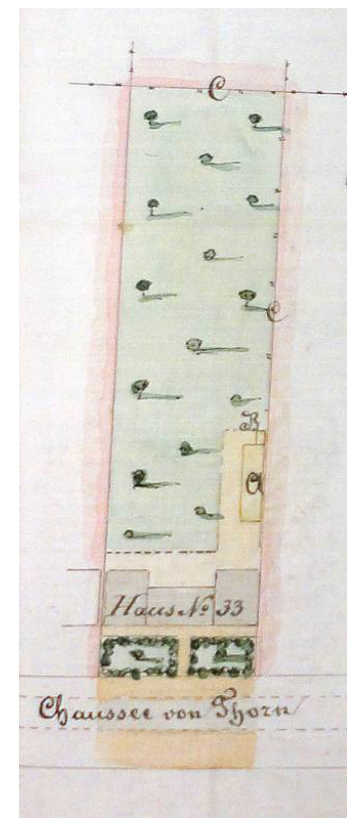

3. Plan sytuacyjny działki o numerze hipotecznym Bromberger Vorstadt Nr 33a (ob. ul. Mickiewicza 81) z widocznym domem poprzedzonym przedogródkiem i ogrodem na tyłach działki. AP Toruń, AmT G 2617, k.5

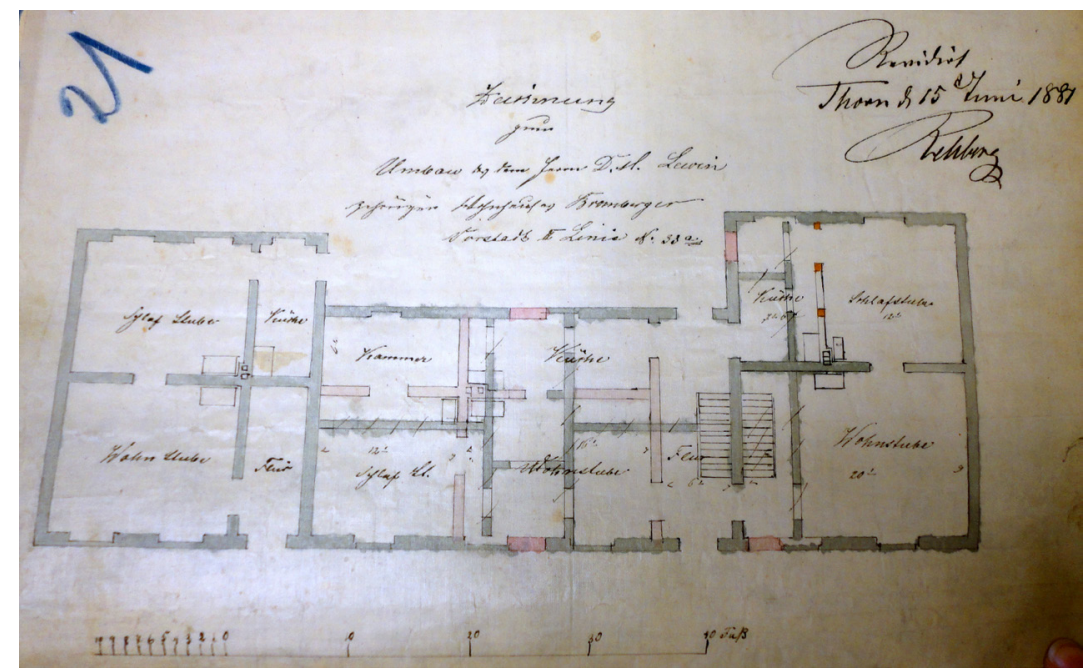

4. Projekt przebudowy domu znajdującego się na działce Bromberger Vorstadt Nr 33a (ob. ul. Mickiewicza 81), rzut parteru, właściciel: David Marcus Lewin, 1881. AP Toruń, AmT G 2617, k.21 
a)

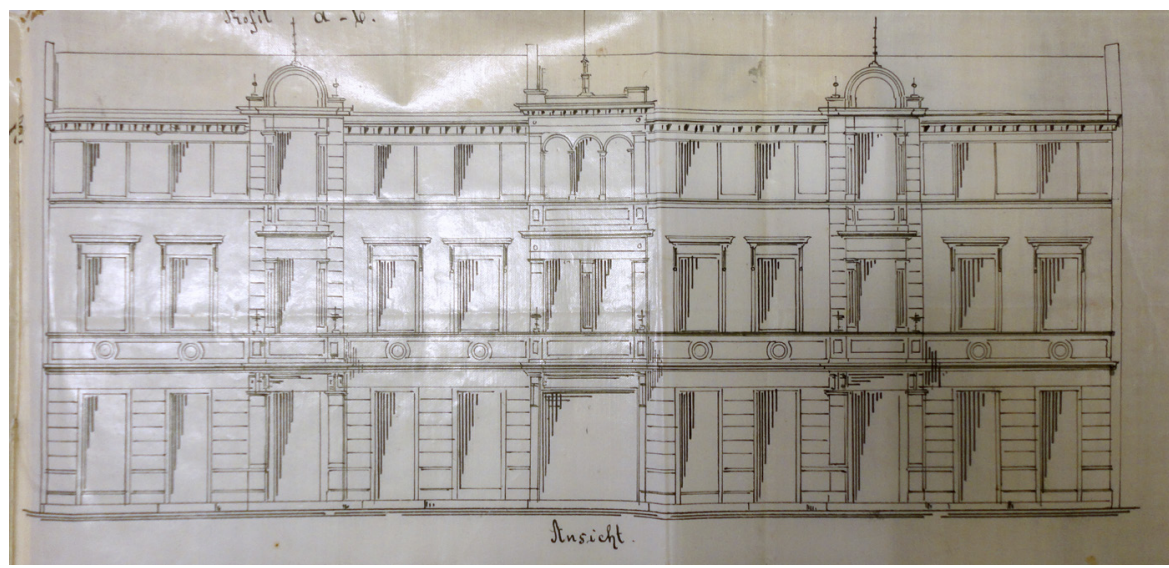

b)

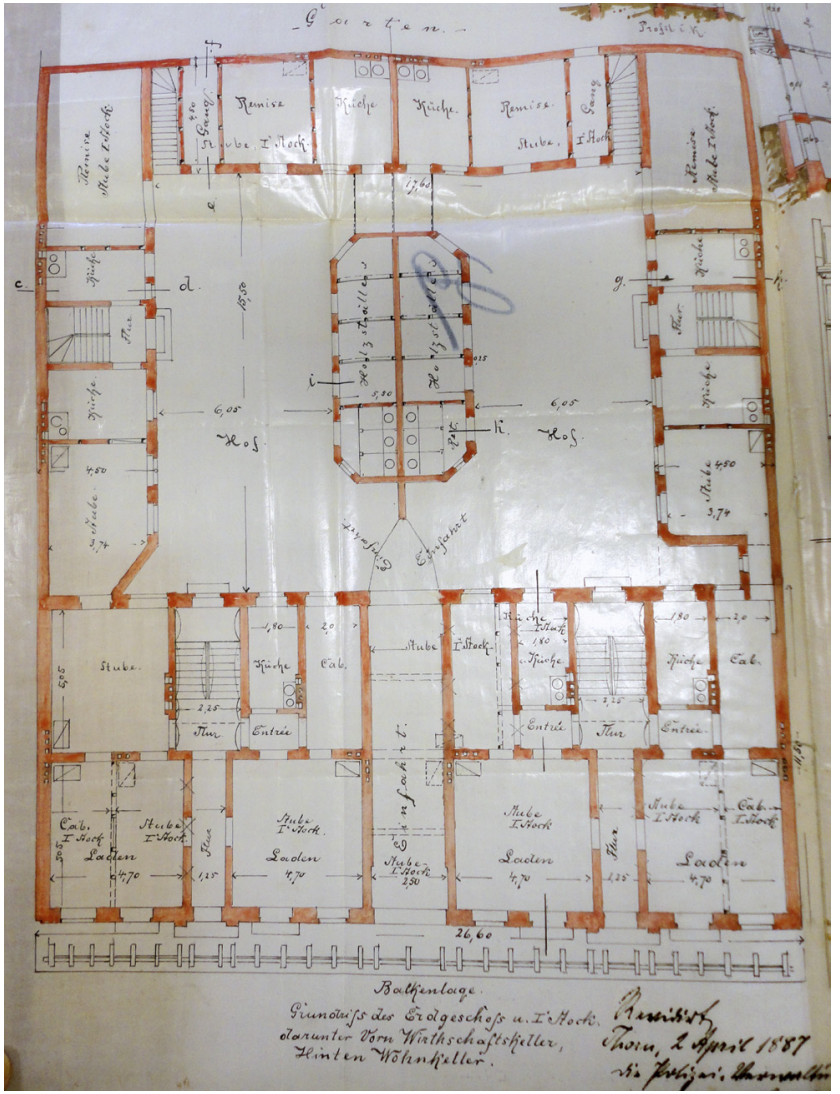

5. Niezrealizowany projekt kamienicy czynszowej na działce przy ul. Mickiewicza 81, widok fasady (a) i rzut parteru (b), proj. wyk. Fr.Geittner (mistrz budowlany), 1887, właściciel Karol Bruschkowski. AP Toruń, AmT G 2617, k.39 


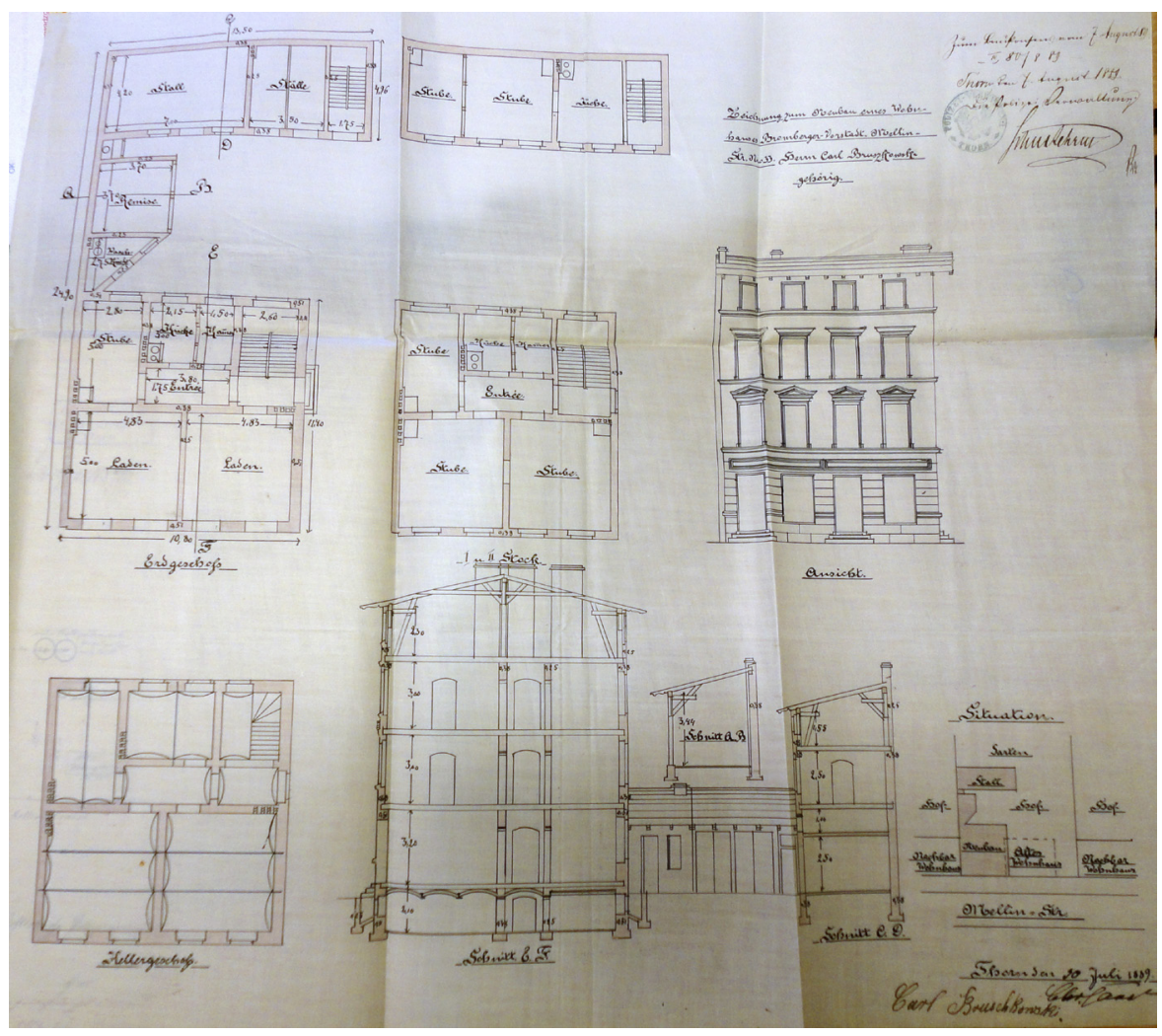

6. Niezrealizowany projekt kamienicy z oficyną boczną i budynkiem gospodarczym, właściciel Carl Bruschkowski, 1889. AP Toruń, AmT G 2617, k.53 


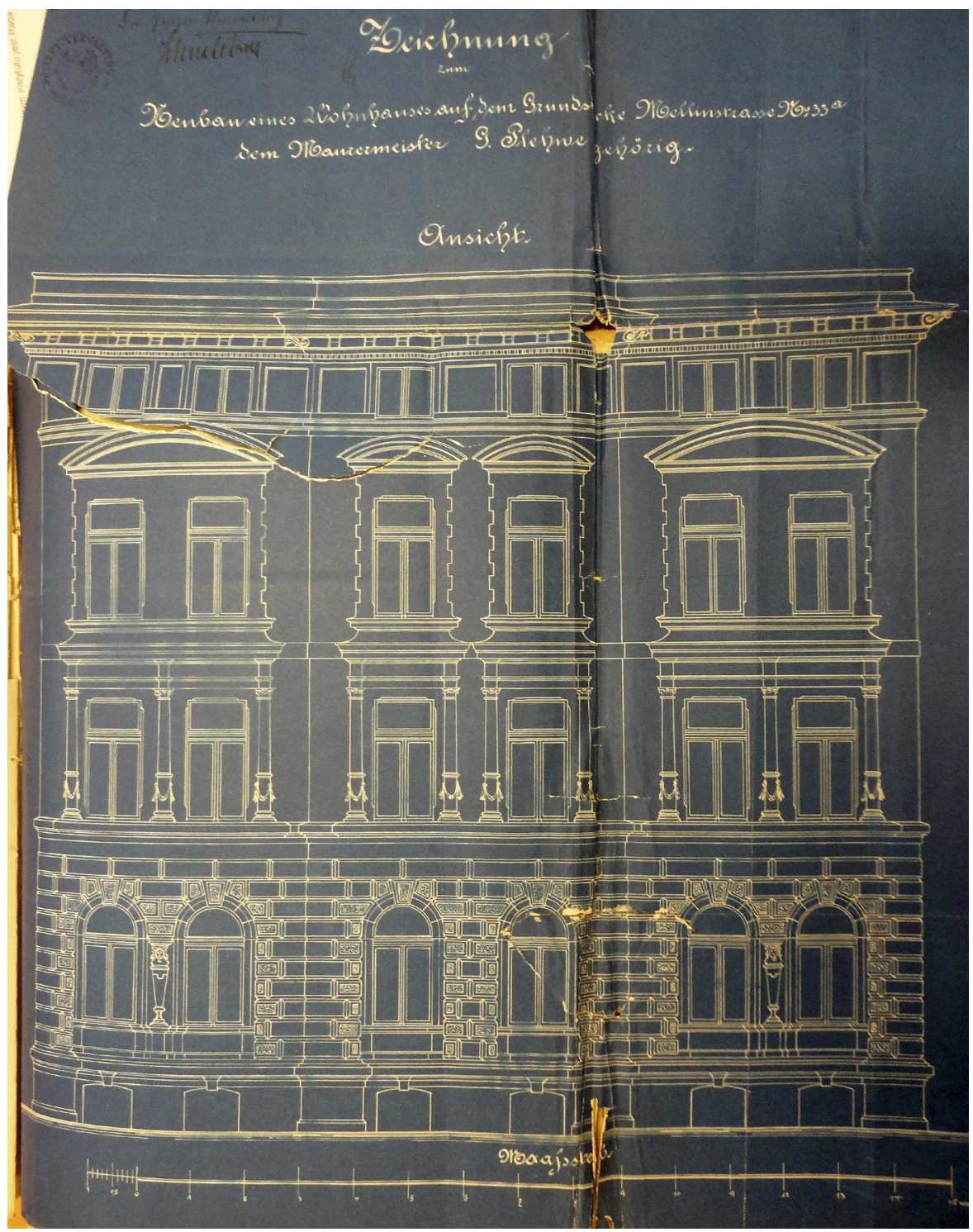

7. Projekt willi miejskiej przy ul. Mickiewicza 81 - widok fasady, właściciel i projektant: Gustaw Plehwe, 1890. AP Toruń, AmT G 2617, k.88 


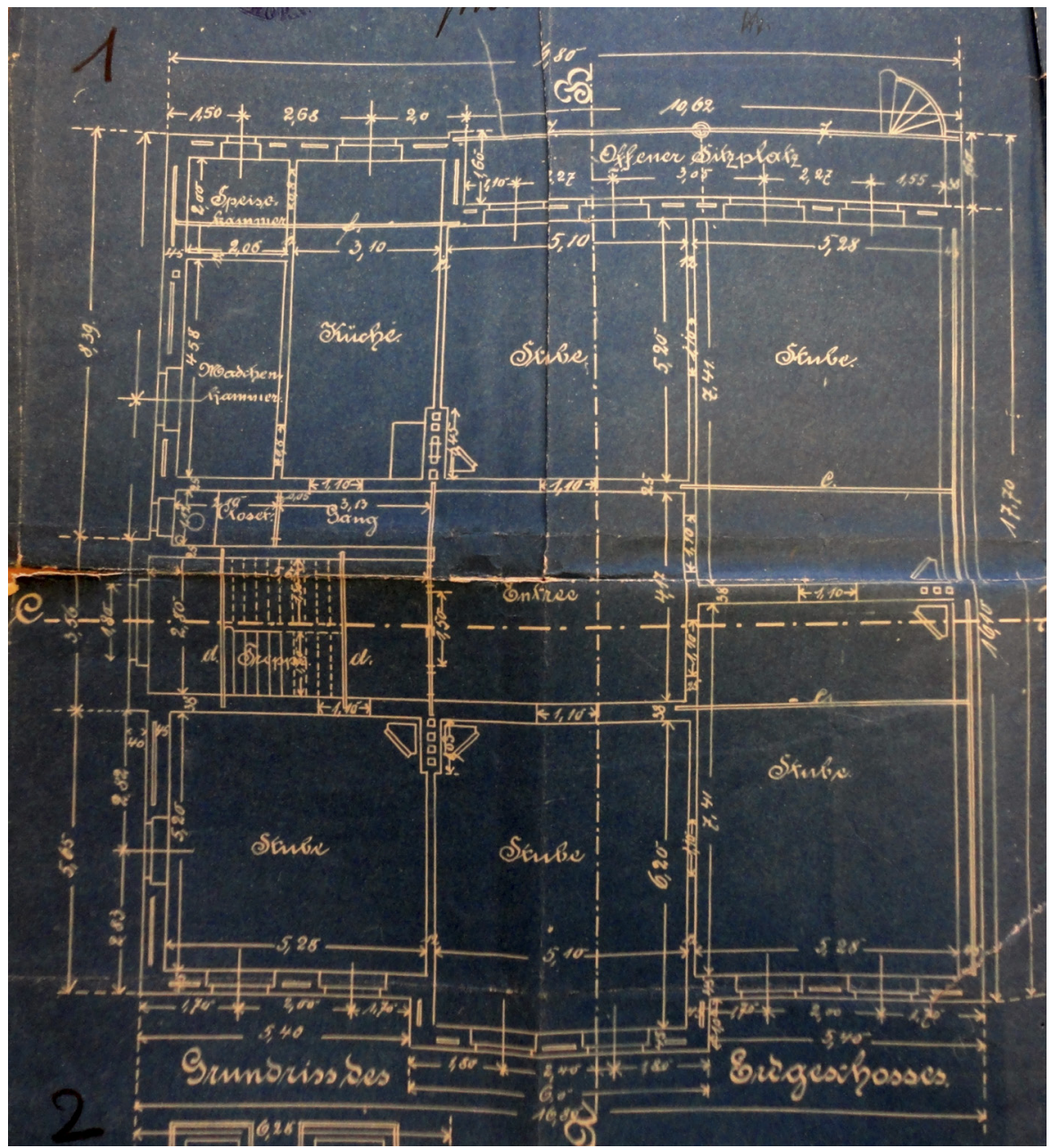

8. Projekt willi miejskiej przy ul. Mickiewicza 81 - rzut parteru, właściciel i projektant Gustaw Plehwe, 1890. AP Toruń, AmT G 2617, k.88 


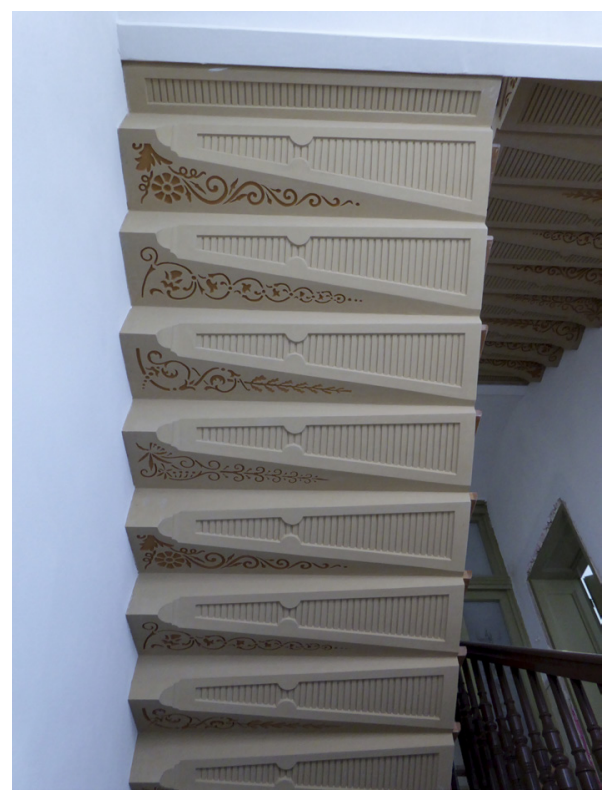

9. Fragment klatki schodowej, betonowe podniebienie schodów, stan w trakcie remontu. Fot. J. Kucharzewska, 2018

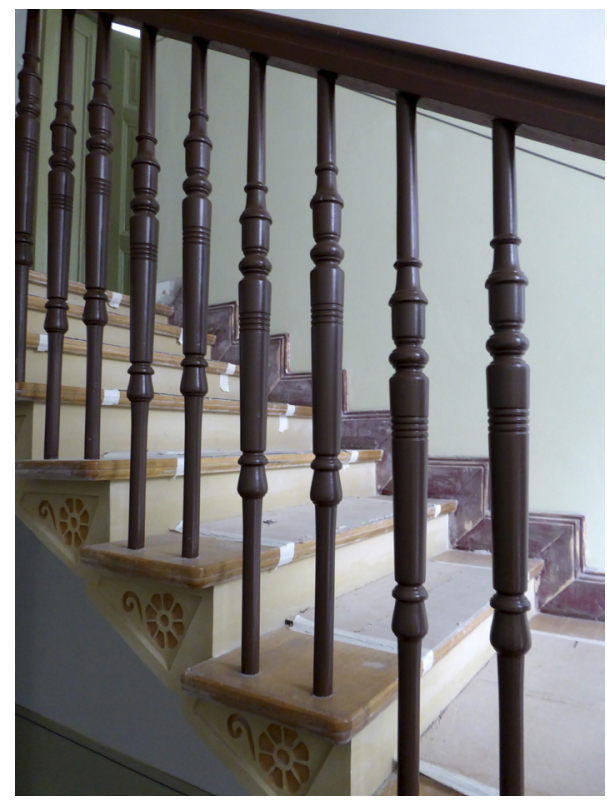

10. Fragment klatki schodowej z dekoracyjnym policzkiem zewnętrznym i podniebieniem, stan w trakcie remontu - oczyszczanie z wtórnych powłok malarskich. Fot. J. Kucharzewska, 2018 


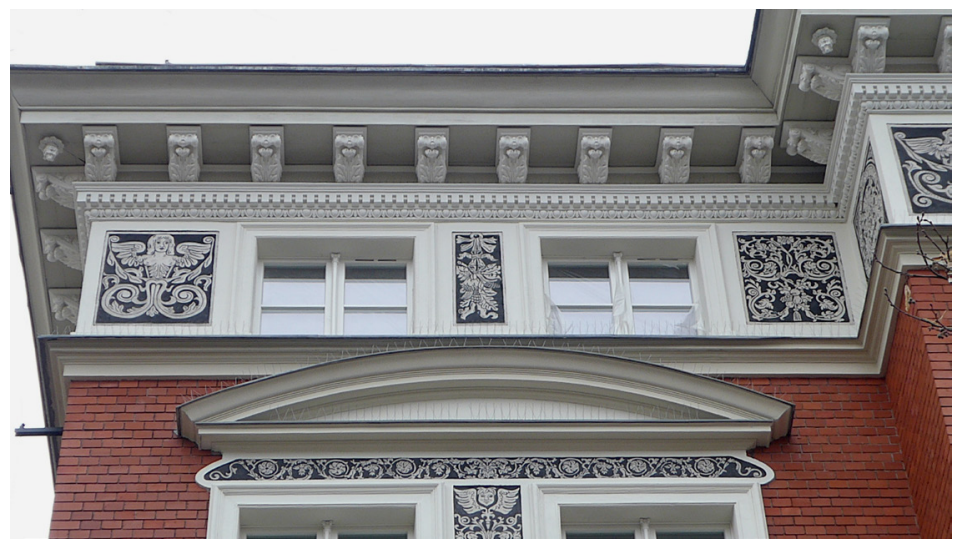

11. Fragment elewacji północnej - detal architektoniczny i dekoracja sgraffito. Fot. J. Kucharzewska, 2018

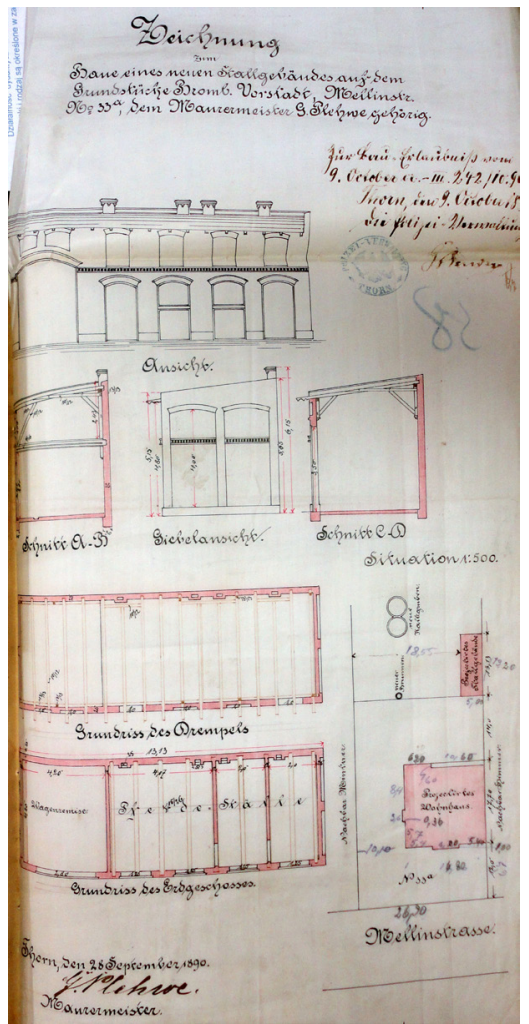

12. Projekt murowanej wolno stojącej oficyny, właściciel i projektant Gustaw Plehwe, 1890. AP Toruń, AmT G 2617, k.58 


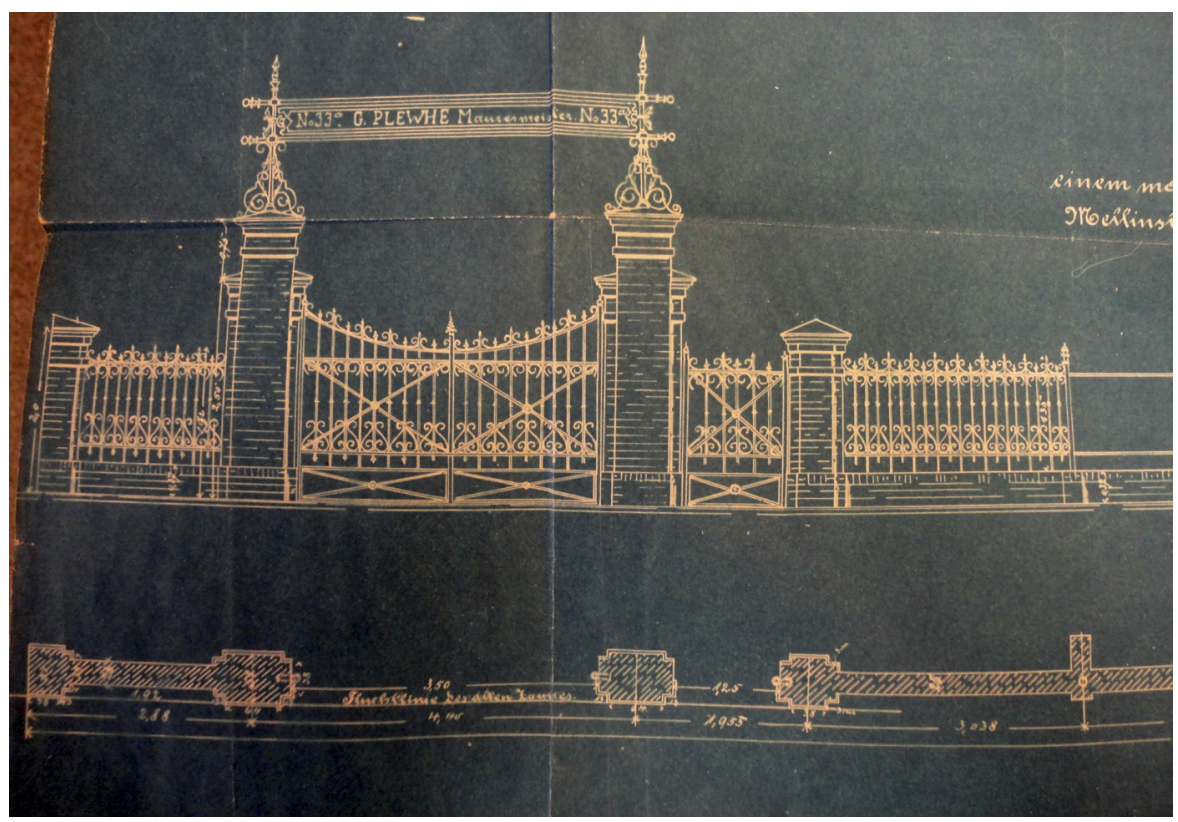

13. Projekt ogrodzenia, właściciel i projektant Gustaw Plehwe, 1890. AmT G 2617, k.99 


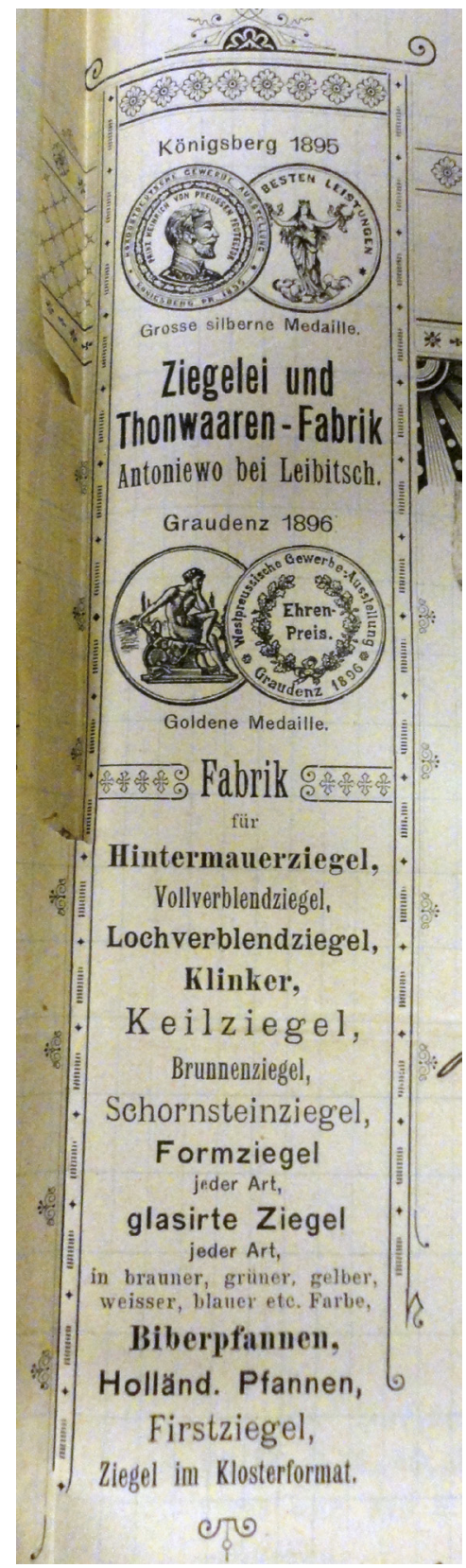

14. Winieta papieru firmowego zakładu Gustawa Plehwy. AP Toruń, AmT G 2617, k.151 


\section{Bibliografia}

\section{Dokumenty źródłowe niepublikowane:}

Archiwum Państwowe w Toruniu, Kart. 283, T. 471.

Archiwum Państwowe w Toruniu, Akta miasta Torunia, akta budowlane, sygn. G 2617. Archiwum Państwowe w Toruniu, Akta miasta Torunia, akta budowlane, sygn. G 2618. Archiwum Państwowe w Toruniu, Akta miasta Torunia, akta budowlane, sygn. F 1031.

\section{Opracowania}

Arszyński, Marian. Zakrzewski, Tadeusz, Toruń. Miasto i ludzie na dawnej fotografii (do 1939 roku), red. Marian Biskup, Toruń: TNT, 1998.

Bałus, Wojciech. „Renesans w wieku XIX i XX: fascynacja i sprzeciw”. W Recepcja renesansu w wieku XIX i XX. Materiały z sesji SHS, 11-33. Łódź: SHS, Muzeum Kinematografii, 2003.

Bałus, Wojciech. „Zjawisko historyzmu w architekturze wieku XIX. Próba opisu”. Dzieła i Interpretacje 3 (1995): 69-80.

Berger, Manfred. Atlas Wohn- und Bürgerhäuser 1846-1902. Berlin: Phoenix, 1986.

Biskup, Krzysztof. „Rejony ograniczeń budowlanych twierdzy gdańskiej w wiekach XIX i XX”. W Gdańsk. Pomnik historii. Cz. 1, red. Artur Kostarczyk, 115-121. Gdańsk: Regionalny Ośrodek Studiów i Ochrony Środowiska Kulturowego, 1998.

Börsch-Supan, Eva. Berliner Baukunst nach Schinkel 1840-1870. München: Prestel, 1977. Brodowska-Kowalska, Marta. „Struktura zawodowa przedmieść Bydgoskiego i Rybaki w Toruniu w latach 1866-1900”. Rocznik Toruński 42 (2015): 25-56.

Brodziński, Kazimierz. „Kurs estetyki, cz. II”. W Pisma Kazimierza Brodzińskiego. [T.] 6, 201-202. Poznań: Gebethner i Wolff, 1873.

Brönner, Wolfgang. Die bürgerliche Villa in Deutschland 1830-1890. Worm: Wernersche Verlagsgesellschaft, 1994.

Ciesielska, Karola. „Mellien Gottlieb”. W Toruński słownik biograficzny. T. 1, red. Krzysztof Mikulski, 172-174. Toruń: UMK, 1998.

Dolgner, Dieter. „Die nationale Variante der Neurenaissance in der deutschen Architektur des 19 Jahrhunderts”. Wissenschaftliche Zeitschrift der Hochschule für Architektur und Bauwesen Weimar 20 (1973): 155-166.

Domińczak, Michał, i Artur Zaguła. Typologia łódzkiej kamienicy. Łódź: Urząd Miasta Łodzi, 2016.

Dyl, Katarzyna. „Socjotopografia Torunia przed I wojną światową na tle rozwoju gospodarczego i ludnościowego miasta w XIX i na początku XX wieku”. Rocznik Toruński 28 (2001): 95-121.

Espérandieu, Henri-Jacques. „Le Sentiment et l'architecture. De la forme et de la coloration des édifices”. Revue générale de l'architecture et des travaux publics 29 (1872): $12-18$. 
Gazeta Toruńska 5 II 1880.

Gazeta Toruńska 24 X 1893.

Geul, Albert. Die Anlage der Wohngebäude. Stuttgart: Weise, 1868 (wyd. 1).

Giętkowski, Mirosław, Zbigniew Karpus, i Waldemar Rezmer. Twierdza Toruń. Toruń: Duet, 2004.

Hermann, Adolph. Neuer führer durch Thorn. Thorn: Dombrowski, 1877.

Jaroszewski, Tadeusz Stefan. „Kostium francuski architektury polskiej 2 poł. XIX w.”

W Od klasycyzmu do nowoczesności, red. Tadeusz Stefan Jaroszewski. Warszawa: PWN, 1995.

Krakowski, Piotr. „Fasada dziewiętnastowieczna”. Zaszyty Naukowe UJ. Prace z Historii Sztuki 16 (1981): 55-95.

Krakowski, Piotr. „Z zagadnień architektury XIX wieku. Historyzm i eklektyzm”. W Sztuka 2 pot. XIX wieku. Materiały sesji SHS, 23-36. Warszawa: PWN, 1973.

Kucharzewska, Joanna. Architektura i urbanistyka Torunia w latach 1871-1920. Warszawa: Neriton, 2004.

Kucharzewska, Joanna. Historia rodziny Weese - fabrykantów toruńskich pierników i jej inwestycje budowlane w Toruniu. Toruń: UMK, 2017.

Kucharzewska, Joanna. „Wybrane inwestycje budowlane Franza Zährera w Toruniu”. Acta Universitatis Nicolai Copernici. Zabytkoznawstwo i Konserwatorstwo 45 (2014): 155-184.

Licht, Hugo. Die Architektur Berlins. Sammlung hervorragender Bauten der letzten zehn Jahre. Berlin: Wasmuth, 1877.

Pagel, Franziska. Ende \& Böckmann. Ein Berliner Architekturbüro im 19 Jahrhundert. Berlin: Mann, 2019.

[Rakowicz, Franciszek]. „Nieco o sprawach miejskich w Toruniu”. Gazeta Toruńska 28 I 1871.

Sas-Zubrzycki, Jan. „Założenia. Szereg spostrzeżeń i uwag z dziedziny architektury”. Przegląd Techniczny 45 (1908).

Schlie, Friedrich. Die Kunst- und Geschichts-Denkmäler des Grossherzogthums Mecklenburg-Schwerin. T. 2 Die Amtsgerichtsbezirke Wismar, Grevesmühlen, Rehna, Gadebusch und Schwerin. Schwerin: Bärensprungschen Hofbuchdr, 1898; Schwerin: Forgotten Books, 1992 (reprint).

Semper, Gottfried. Kleine Schriften. Berlin-Stuttgart: W. Spemann, 1884.

Skuratowicz, Jan. „'Wersale północy’, czyli o rezydencjach europejskich 2 poł. XIX w.” W Tradycja i innowacja. Materiały z sesji SHS, 241-259. Warszawa: PWN, 1981.

Spandowski, Szymon. „Na marginesie jubileuszu Nowości”. Nowości 16 X 2017. Spandowski, Szymon. „Nowości w tym roku kończą 50 lat”. Nowości 8 X 2017.

Tołłoczko, Zdzisława. „Kostium francuski w architekturze XIX wieku i jego recepcja na ziemiach Polski na przykładzie pałaców w Świerklańcu i Kronenberga w Warszawie”. Wiadomości Konserwatorskie 48 (2016): 106-118. 
Wajda, Kazimierz. „Pod ponownym pruskim panowaniem (1815-1920)”. W Toruń dawny i dzisiejszy. Zarys dziejów, red. Marian Biskup, 329-416. Warszawa-Poznań-Toruń: PWN, 1983.

Wierzchosławski, Szczepan. „Toruń w początkach 1871 roku. Obraz miasta w świetle ówczesnej Gazety Toruńskiej”. Rocznik Toruński 25 (1998): 29-41.

Zeitschrift für Bauwesen 40 (1890): 175-178.

Zgórniak, Marek. „Wokół neorenesansu w architekturze XIX wieku”. Zeszyty Naukowe UJ. Prace z Historii Sztuki 18 (1987): 1-143.

Zgórniak, Marek. Wokół neorenesansu w architekturze XIX wieku. Kraków: Marek Zgórniak, 2013.

Dokumentacje i opracowania konserwatorskie niepublikowane:

Bulderberg, Irena. „Dokumentacja prac konserwatorskich prowadzonych na elewacji północnej i wschodniej kamienicy przy ul. Mickiewicza 81 w Toruniu”. Dokumentacja konserwatorska, Toruń 1996, Archiwum MKZ w Toruniu.

Kucharzewska, Joanna. „Analiza historycznej kompozycji przestrzennej Przedmieścia Bydgoskiego i Rybaków od średniowiecza do 1914 roku”. Dokumentacja konserwatorska, Toruń 2009, Archiwum WUKZ w Toruniu.

Kucharzewska, Joanna. „Karta ewidencyjna zabytku nieruchomego - Budynek mieszkalny przy ul. Mickiewicza 81 w Toruniu”. Dokumentacja konserwatorska, Toruń 2018, Archiwum WUKZ w Toruniu.

Kucharzewska, Joanna. „Kwerenda archiwalna dotycząca budynków przy ul. Mostowej 30 i Podmurnej 29 w Toruniu”. Dokumentacja konserwatorska, Toruń 2018, Archiwum MKZ w Toruniu.

Kucharzewska, Joanna, i Piotr Dąbrowski. „Program prac konserwatorskich dla budynku przy ul. Sienkiewicza 33 w Toruniu (dawne kasyno wojskowe)”. Dokumentacja konserwatorska, Torun 2017, Archiwum MKZ w Toruniu.

Zaręba, Anna. „Program prac konserwatorskich kamienicy przy ul. Mickiewicza 81 w Toruniu”. Dokumentacja konserwatorska, Toruń 2017, Archiwum MKZ w Toruniu.

\section{Netografia:}

http://twierdza.poznan.pl/kamienie/. Dostęp 30.05.2018.

Ilustrowana historia Bydgoskiego Przedmieścia w Toruniu. Dostęp 30.05.2018.

http://bydgoskie.blox.pl/html/1310721,262146,21.html. 